\title{
GSK3 $\beta$ : A Master Player in Depressive Disorder Pathogenesis and Treatment Responsiveness
}

\author{
Przemysław Duda *๑) Daria Hajka $₫$, Olga Wójcicka $₫$, Dariusz Rakus $₫$ and \\ Agnieszka Gizak *(i) \\ Department of Molecular Physiology and Neurobiology, University of Wrocław, Sienkiewicza 21, \\ 50-335 Wrocław, Poland; daria.hajka@uwr.edu.pl (D.H.); olga.wojcicka@uwr.edu.pl (O.W.); \\ dariusz.rakus@uwr.edu.pl (D.R.) \\ * Correspondence: przemyslaw.duda@uwr.edu.pl (P.D.); agnieszka.gizak@uwr.edu.pl (A.G.); \\ Tel.: +48713754135 (A.G.)
}

Received: 4 February 2020; Accepted: 14 March 2020; Published: 16 March 2020

\begin{abstract}
Glycogen synthase kinase $3 \beta$ (GSK3 $\beta$ ), originally described as a negative regulator of glycogen synthesis, is a molecular hub linking numerous signaling pathways in a cell. Specific GSK3 $\beta$ inhibitors have anti-depressant effects and reduce depressive-like behavior in animal models of depression. Therefore, GSK3 $\beta$ is suggested to be engaged in the pathogenesis of major depressive disorder, and to be a target and/or modifier of anti-depressants' action. In this review, we discuss abnormalities in the activity of GSK3 $\beta$ and its upstream regulators in different brain regions during depressive episodes. Additionally, putative role(s) of GSK3 $\beta$ in the pathogenesis of depression and the influence of anti-depressants on GSK3 $\beta$ activity are discussed.
\end{abstract}

Keywords: GSK3 $\beta$; MDD; depression; anti-depressants; AKT; BDNF; neuroprotection

\section{Introduction}

\subsection{Major Depressive Disorder}

According to the World Health Organization's statistics for March 2018, depression is a major contributor to the overall global burden of diseases. Globally, more than 300 million people suffer from depression. In the Diagnostic and Statistical Manual of Mental Disorders (DMS-5), major depressive disorder (MDD), the principal form of depression, is characterized by the following key symptoms: depressed mood and anhedonia (which are the fundamental symptoms), suicidal ideation, plan or attempt, fatigue, sleep deprivation, loss of weight and appetite, and psychomotor retardation [1]. The first effective treatment for MDD was established in the 1950s when anti-depressant effects of iproniazide and imipramine were discovered. Iproniazide, originally described as an anti-tuberculosis drug, was found to be the first monoamie oxidase inhibitor (MAOi), whereas imipramine, an anti-histamine drug, was studied as an antipsychotic for use in patients with schizophrenia [2,3]. Latter, imipramine became one of the first members of tricyclic anti-depressants (TCAs). These findings resulted in the monoaminergic hypothesis of the MDD pathogenesis, which assumes that MDD is caused by a reduction in noradrenaline (NA) and serotonin (5-HT) neurotransmission [4]. In the current pharmacotherapy of depression, three main groups of drugs are available: TCAs, the first generation of anti-depressants, selective serotonin reuptake inhibitors (SSRIs), and selective serotonin and noradrenaline reuptake inhibitors (SSNRIs, the second generation). In addition, medications, such as $\alpha 2$-receptor blockers, MAOis, selective noradrenaline reuptake inhibitors (SNRIs), selective noradrenaline and dopamine reuptake inhibitors (SNDRIs), melatonin receptor agonists and serotonin $5-\mathrm{HT}_{2 \mathrm{C}}$ receptor antagonists, are used in the treatment of depression. Some anti-depressants, such as trazodone, do not belong to 
any of the groups listed above. Additionally, electroconvulsive therapy, conducted for the first time in 1938 , is still widely used in the treatment of MDD, especially in its drug-refractory form [5].

Although the monoaminergic hypothesis has led to the invention of many successful therapeutic strategies based on the elevation of levels of NA and 5-HT in the synaptic cleft, it does not explain the anti-depressant effect of lithium and the rapid action of ketamine in the treatment of mood disorders [6]. Therefore, factors other than neurotransmission must be taken into consideration in the context of the MDD pathogenesis. One of them is glycogen synthase kinase $3 \beta$ (GSK3 $\beta$ ) signaling.

\subsection{Glycogen Synthase Kinase $3 \beta$}

GSK3 was isolated in 1980, from rabbit skeletal muscle, and described as a highly specific serine/threonine kinase for glycogen synthase [7]. There are two isozymes of GSK3, $\alpha$ and $\beta$, and both are expressed at similar levels in the mouse brain [8]. In the human brain, the $\beta$ isozyme predominates [9]. Therefore, GSK3 $\beta$ is expected to be crucial for the human central nervous system functioning. The activity of GSK3 $\beta$ is regulated positively and negatively by phosphorylation on Tyr216 and Ser9, respectively [10,11]. Whereas phosphorylation of the residue Tyr216 occurs during the GSK3 $\beta$ translation process and results in a synthesis of the fully activated kinase, Ser9 phosphorylation seems to be the main regulatory modification during the enzyme lifespan [12]. Ser9-phosphorylated GSK3 $\beta$ remains inhibited, and dephosphorylation of the residue results in the disinhibition (activation) of the kinase.

GSK3 $\beta$ is part of numerous cellular signaling pathways, and its activity can be regulated, directly or indirectly, by several kinases, phosphatases, and proteases. The wide spectrum of GSK3 $\beta$ substrates, including transcription factors, glycolytic enzymes, pro- and anti-apoptotic factors, mitochondrial channels, membrane receptors, and cytoskeleton-associated proteins, makes GSK3 $\beta$ a central point of the cell homeostasis maintenance [13]. The activity of GSK3 $\beta$ affects energy metabolism, cell survival, proliferation, apoptosis, membrane polarity, internalization of the synaptic receptors, neuroplasticity, neurotransmission, amyloid processing, and many other processes [13].

Extracellular factors, such as insulin or insulin-like growth factor 1 (IGF-1), epidermal growth factor (EGF), platelet-derived growth factor (PDGF), and transforming growth factor $1 \beta$ (TGF-1 $\beta$ ), acting via the phosphoinositide 3-kinase/protein kinase B (PI3K/AKT) pathway, inhibit GSK3 $\beta$ by phosphorylation of Ser9 of the kinase [14-16]. The same effect is mediated by mitogen-activated protein kinase/extracellular signal-regulated kinase (MAPK/ERK) pathway activity upon EGF, fibroblast growth factor (FGF), PDGF, nerve growth factor (NGF), and brain-derived neurotrophic factor (BDNF) stimulation, and as a result of cytokine action via p38 MAPK [17-19]. Inactivation of GSK3 $\beta$ may also be an effect of protein kinase A (PKA) activity (stimulated by. e.g., elevated cAMP level), integrin-linked kinase (ILK), calcium/calmodulin dependent protein kinase 2 (CaMK2) and WNT signaling [16,20-22]. On the other hand, dephosphorylation of Ser9 by protein phosphatase 1 (PP1), protein phosphatase 2A (PP2A), and protein phosphatase 2B (PP2B, calcineurin) directly activates GSK3 $\beta$ [23]. It is noteworthy that the majority of the proteins mentioned above are involved in intracellular processes related to neurotransmission and neuroplasticity.

\subsection{GSK3 $\beta$ Activity in Neurotransmission and Neuroplasticity}

Glutamate, the most abundant excitatory neurotransmitter in the vertebrate central nervous system, acts through $\alpha$-amino-3-hydroxy-5-methyl-4-izoxazole propionic acid receptors (AMPAR) and $N$-methyl-D-aspartate receptors (NMDAR). Whereas AMPARs are responsible for membrane depolarization upon glutamate binding, NMDARs, conducting calcium current, are directly associated with neuroplasticity [24]. The activity of NMDARs results in a high cytosolic calcium concentration $\left(\left[\mathrm{Ca}^{2+}\right]_{\mathrm{c}}\right)$ and leads to calcium/calmodulin-dependent protein kinase 2 (CaMK2) activation. In contrast, modest $\left[\mathrm{Ca}^{2+}\right]_{c}$ causes calcineurin activation [25]. Both enzymes are known to modify Ser9 residue of GSK3 $\beta$. CaMK2 stimulates its phosphorylation and thus, inhibits GSK3 $\beta$, while calcineurin induces its dephosphorylation and activates the kinase $[22,26]$. A change in cellular $\left[\mathrm{Ca}^{2+}\right]_{\mathrm{c}}$ underlies the 
NMDAR-dependent neuroplasticity phenomena called long-term potentiation (LTP) and long-term depression (LTD). LTP is a process of strengthening of synapses caused by NMDAR-activation-evoked high $\left[\mathrm{Ca}^{2+}\right]_{\mathrm{c}}$. Calcium ions activate CAMKs leading to the incorporation of AMPARs into the postsynaptic membrane and synthesis of new subunits of AMPAR [27]. In contrast to LTP, LTD is a process of weakening of synapses in which AMPARs are internalized due to the modest- $\left[\mathrm{Ca}^{2+}\right]_{c}$-induced activation of protein phosphatases, including calcineurin. As a result, dephosphorylated (and activated) GSK3 $\beta$ phosphorylates postsynaptic density protein 95 (PSD95) and kinesin light chain 2 which regulates AMPARs internalization [28].

To summarize, active GSK $3 \beta$ is related to the downsizing of synapses and decreased excitability of neurons, whereas inhibition of GSK3 $\beta$ is necessary for the induction of LTP, the process underlying new memory formation.

$\gamma$-aminobutyric acid (GABA) is a main inhibitory neurotransmitter in the central nervous system. Its receptors, ionotropic $\mathrm{GABA}_{\mathrm{A}}$ and metabotropic $\mathrm{GABA}_{\mathrm{B}}$ receptors, group in inhibitory synapses together with gephyrin, a scaffolding protein [29]. GSK3 $\beta$ phosphorylates gephyrin, which induces the formation of new GABAergic synapses [30]. On the other hand, GABAergic transmission inhibits GSK3 $\beta$ by acting through $G_{A B A}$ receptors, which stimulate the activity of AKT in a $\beta$-arrestin 2-dependent manner [31].

Another neurotransmitter that can modify the activity of GSK3 $\beta$ is dopamine (DA). DA is involved in motor control, motivation, reward, and executive functions. The effects of its signaling on GSK3 $\beta$ depend on the type of DA receptors expressed on the neuronal surface. Stimulation of Dopamine Receptor 1 (D1R) and Dopamine Receptor 3 (D3R) activates adenylyl cyclase and inhibits GSK3 $\beta$ through PKA and AKT action [32]. Dopamine Receptor 2 (D2R) inhibits AKT via activation of $\beta$-arrestin 2/PP2A complex and leads to GSK3 $\beta$ activation [33].

GSK3 $\beta$ activity can also be affected by $5-\mathrm{HT}$ signaling. Stimulation of $5-\mathrm{HT}_{1}$ and $5-\mathrm{HT}_{7}$ activates the PI3K/AKT pathway and thus, increases Ser9 phosphorylation in GSK3 $\beta$, while activation of $5-\mathrm{HT}_{2 \mathrm{~A}} \mathrm{R}$ has the opposite effect $[34,35]$.

NA inhibits GSK3 $\beta$ activity acting through the $\alpha 1 \mathrm{~A}$-adrenergic receptor $(\alpha 1 \mathrm{AAR})$ and stimulating phosphorylation of GSK3 $\beta$ Ser9 via protein kinase C (PKC) [36], and through $\alpha 2$ - and $\beta$-adrenergic receptors $(\alpha 2 \mathrm{AR}$ and $\beta \mathrm{AR})$ via PKA $[37,38]$.

The relationship between GSK3 $\beta$ and neurotransmitters is schematically presented in Figure 1.

Concluding, GSK3 $\beta$ is a hub that links different molecular pathways within a cell. The activity of the kinase, affected by the action of neurotransmitters, mediates neuroplasticity and directs neurons towards synaptic potentiation or depression route. Thus, because MDD is believed to be a result of dysregulation in neurotransmitters actions in different brain regions, GSK3 $\beta$ can be considered as a factor engaged in the MDD pathogenesis and development. 


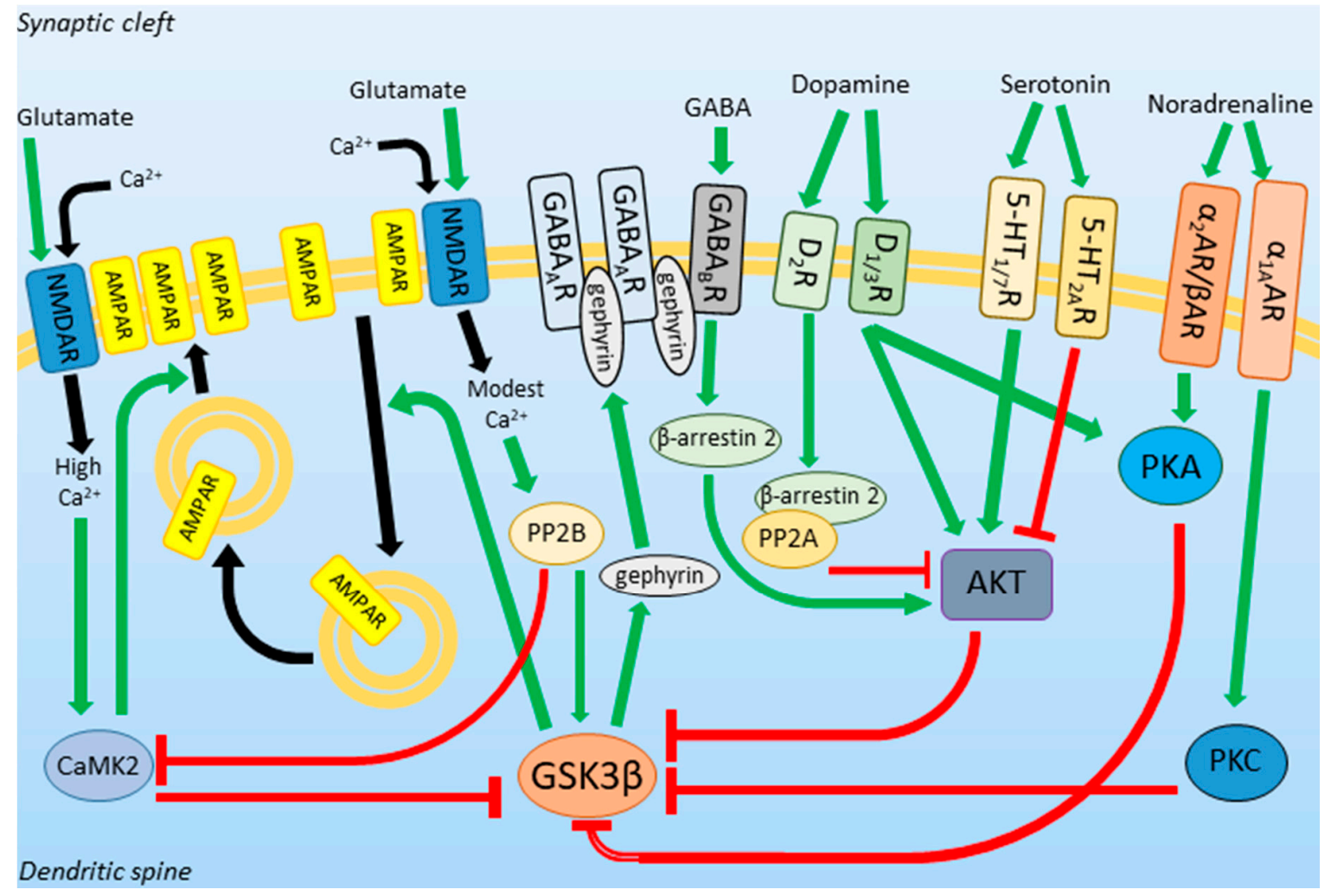

Figure 1. Neurotransmitters acting through protein kinases and phosphatases regulate glycogen synthase kinase $3 \beta$ (GSK3 $\beta$ ) activity. GSK3 $\beta$ influences the strength of excitatory and inhibitory synapses. Green arrows represent activation, red arrows represent inhibition, black arrows represent translocation. Abbreviations: NMDAR: $N$-methyl-D-aspartate receptor, AMPAR: $\alpha$-amino-3-hydroxy-5-methyl-4-izoxazole propionic acid receptor, $\mathrm{GABA}_{\mathrm{B}} \mathrm{R}: \gamma$-aminobutyric acid receptor type $B, D_{1 / 2 / 3} R$ : dopamine receptors, $5-H_{1 / 2 A / 7} R$ : serotonin receptors, $\alpha_{1 A} / \alpha_{2} / \beta A R$ : adrenergic receptors, PKA: protein kinase A, AKT: protein kinase B, PKC: protein kinase C, PP2A/2B: protein phosphatases 2A/2B, CaMK2: calcium/calmodulin dependent protein kinase 2, GSK3 $\beta$ : glycogen synthase kinase $3 \beta$.

\section{GSK3 $\beta$ Expression Profile and Activity in Depression}

Expression profile, haplotypes, and activity of GSK3 $\beta$ have been intensively studied in a broad range of psychiatric and neurological diseases, such as schizophrenia, Parkinson's, and Alzheimer's diseases [13], and in the context of mood disorders [39]. It has been found that the total amount of GSK3 $\beta$ protein is unchanged, whereas its activity is significantly enhanced in the prefrontal cortex (PFC) of depressed patients and depressed suicide victims, but not in suicides without a psychiatric history. This suggests a role of GSK3 $\beta$ in MDD but not in suicide per se $[40,41]$.

The increase on GSK3 $\beta$ activity has also been found in platelets of depressed patients [42,43], whereas the GSK $3 \beta$ gene expression was upregulated in such brain structures as the frontal cortex, raphe, and hippocampus in the rat model of depression [44].

Anhedonia and loss of motivation are some of the main MDD symptoms. They are caused by a disrupted interplay between different brain structures, such as ventral tegmental area, nucleus accumbens, and cingulate cortex, which can be grouped in the so-called reward circuit [45]. Wilkinson et al. demonstrated that in the nucleus accumbens, a key region of the circuit, the amount of Ser9-phosphorylated GSK3 $\beta$ is downregulated in the mouse social defeat model of depression [46]. The increased activity of the kinase can be observed in susceptible, but not in resilient animals. Additionally, a similar pro-depression-like effect can be induced by GSK3 $\beta$ overexpression in the nucleus accumbens, while the expression of inactive GSK3 $\beta$ mutant promotes resilience to social defeat stress [46]. On 
the other hand, Crofton et al., found that the knockdown of GSK3 $\beta$ in the nucleus accumbens shell increases cocaine self-administration and depression-like behavior in social contact tests in rats $[47,48]$. This discrepancy between stressor type and its effect within the same structure is also reflected in the activity of the ventral tegmental area, a midbrain structure that delivers input to nucleus accumbens. It has been shown that chronic social defeat stress enhances the phasic firing rate of the ventral tegmental area neurons in defeated rodents [49]. However, chronic stress can also lead to atrophy of the ventral tegmental area system [50]. It has been hypothesized that these opposing outcomes might be due to a different nature of the stressors, the heterogeneity of ventral tegmental area cells, or the time of day when the experiments were performed [51]. Interestingly, it has been found that the level of Ser9-phosphorylated GSK3 $\beta$ in the ventral tegmental area and other reward-related brain structures in naïve rats shows significant circadian rhythmicity [52].

The activity of AKT, a negative upstream regulator of GSK3 $\beta$, is decreased in the prefrontal cortex of depressed suicide victims [40]. In line with this, decreased AKT activity in the ventral tegmental area increases susceptibility to depressive-like behaviors in a rodent model [53].

Interestingly, different haplotypes of GSK3 $\beta$ seem to be related to MDD severity, age of onset, and drug responsiveness. Single nucleotide polymorphism (SNP) rs6782799 in GSK3 $\beta$ gene has been demonstrated to be important for susceptibility to MDD by modification of the relationship between negative life events and depression [54,55]. Another SNP, rs334555, alters the age of MDD onset. Its $C / C$ and $C / G$ genotypes are associated with the late age of onset (about 46 and 41 years old on average, respectively), whereas its G/G genotype with the early (about 28 years old on average) onset of depression [56]. Although rs334555 has no direct effect on GSK3 $\beta$, it is in a moderate linkage disequilibrium with rs6438552, which is an intronic SNP related to the altered splicing and increased level of the GSK3 $\beta$ transcript in lymphocytes [57].

rs6438552 has been associated with a lowered volume of grey matter both in right and in left superior temporal gyri, and right hippocampus of MDD patients [58]. Additionally, rs6438552, together with rs334558, has been linked to anxiety-like behavior in MDD [59]. rs334558, a promoter SNP related with enhanced GSK3 $\beta$ transcription [57], is associated with remission upon anti-depressant drugs administration [60].

Summarizing, the activity of GSK3 $\beta$ in different brain regions is affected by stress, and haplotypes of the kinase determine a severity, age of onset, and drug responsiveness in MDD.

\section{Putative Role of GSK3 $\beta$ in the MDD Pathogenesis}

The current pharmacotherapy of MDD originates from the monoaminergic hypothesis. However, the MDD pathogenesis appears to be more complex. Various animal models of depression have been established: olfactory bulbectomy, learned helplessness, maternal separation, social isolation, chronic unpredictable/mild stress, witness defeat, and many others. None of them fully recapitulated the entire human depression syndrome [61]. This suggests that the MDD onset engages many cellular processes and factors. Most of them can be directly or indirectly linked to altered GSK3 $\beta$ activity. The place of GSK3 $\beta$ in different molecular pathways is schematically presented in Figure 2. 


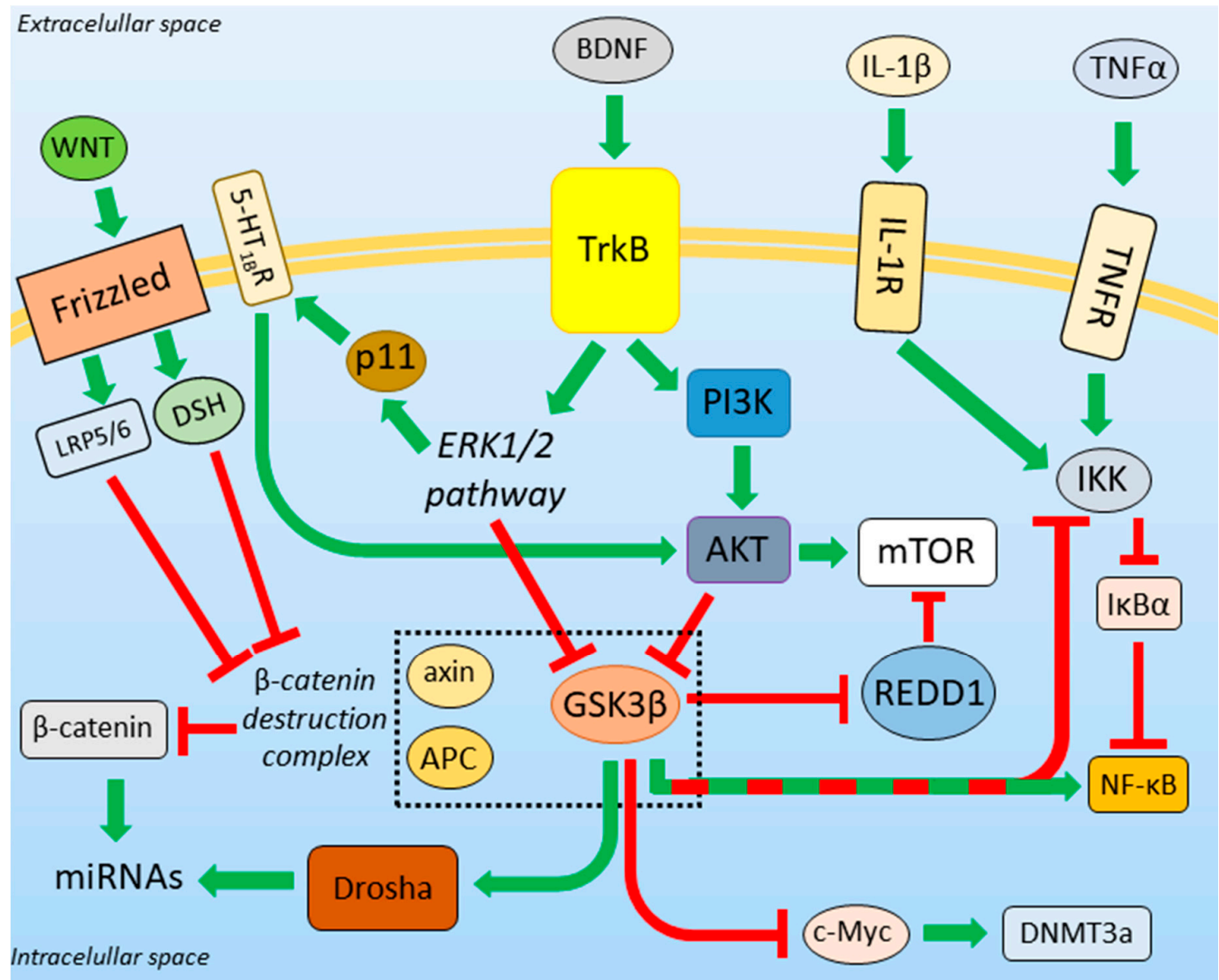

Figure 2. GSK3 $\beta$ is a part of neurotrophic and pro-inflammatory factors signaling pathways. Green arrows represent activation, red arrows represent inhibition. Green-red arrow denotes a dual, dependent on the physiological state of a cell, action of GSK3 $\beta$. Abbreviations: WNT: Wingless-related integration site, LRP5/6: low-density lipoprotein receptor-related protein 5 and 6, DSH: Disheveled, $5-\mathrm{HT}_{1 \mathrm{~B}} \mathrm{R}$ - serotonin $1 \mathrm{~B}$ receptor, ERK: extracellular signal-regulated kinase, APC: adenomatous polyposis coli, BDNF: brain-derived neurotrophic factor, TrkB: tropomyosin receptor kinase B, PI3K: phosphoinositide 3-kinase, AKT: protein kinase B, IL-1 $\beta$ : interleukin $1 \beta$, IL-1R: interleukin $1 \beta$ receptor, TNF $\alpha$ : tumor necrosis factor $\alpha$, TNFR: tumor necrosis factor $\alpha$ receptor, IKK: IKB kinase, $\mathrm{I} \kappa \mathrm{B} \alpha$ : nuclear factor of light polypeptide gene enhancer in B-cells inhibitor $\alpha, \mathrm{NF}-\kappa \mathrm{B}$ : Nuclear factor $\kappa$-light-chain-enhancer of activated B cells, mTOR: mammalian target of rapamycin, REDD1: regulated in development and DNA damage response-1, DNMT3a: DNA methyltransferase 3a, GSK3 $\beta$ : glycogen synthase kinase $3 \beta$.

\subsection{GSK3 $\beta$ in the Animal Models of Depression}

In 1949, Cade suggested that lithium, the classical mood stabilizer, might be a possible therapeutic for psychiatric diseases based on its behavioral effects in guinea pigs [62]. Since then, the rodent behavioral characteristics have become the high-value models in mood disorders treatment studies [39]. The discovery that GSK3 $\beta$ is a direct target of lithium action [63] has raised the possibility that lithium exerts its effects through the modulating activity of the kinase. To identify the mood-altering role of GSK3 $\alpha$ and $\beta$ isozymes, molecular methods have been employed in various animal models of depression.

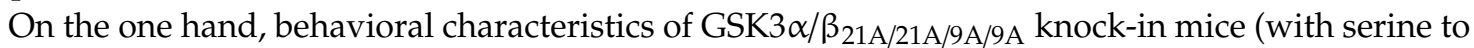
alanine mutations to block inhibitory phosphorylation of serine 21 and 9 in GSK3 $\alpha$ and $\beta$, respectively) demonstrated that the animals exhibited a heightened response to a novel environment and that administration of amphetamine causes over 2.5-fold greater hyperactivity compared to control mice [64]. 
It emphasized the importance of GSK3 $\alpha / \beta$ activity in the development of manic-like disturbances. On the other hand, the knock-in animals showed increased vulnerability to stress-induced depressive-like behavior in the learned helplessness, forced swim, and tail suspension tests [64]. Additionally, the lack of adaptability of these knock-in mice to stress involved also anxiety, which often coexists with depression. The animals displayed a mild-anxious behavior in the elevated plus maze [64]. Later, using GSK3 $\beta$ knock-in mice, it has been established that increased activity of the $\beta$ isozyme of GSK3 is sufficient to impair mood regulation in learned helplessness model of depressive-like behavior, whereas GSK3 $\alpha$ activity alone does not impair this process [65].

Bilateral intra-hippocampal injections of lentivirus expressing shRNA anti-Gsk $3 \beta$ induce an antidepressant-like effect in chronically stressed mice in the forced swim and tail suspension tests [66]. Moreover, heterozygous loss of Gsk3 $\beta$ causes behavioral defects that mimic the action of lithium [67], whereas transgenic expression of Gsk3 $\beta$ in $G s k 3 \beta^{+/-}$heterozygotes reverses these defects [68]. Additionally, the same effect is observed when GSK3 $\beta$ is overexpressed in lithium-treated mice [68]. Rescue of the heterozygous loss of Gsk3 $\beta$ or lithium-induced phenotype by restoring the activity of GSK3 $\beta$ strongly supports the hypothesis that the phenotype is due to specific inhibition of the kinase.

\subsection{Inhibitors of GSK3 $\beta$ in Depression}

Several lines of evidence have shown that GSK3 $\beta$ contributes to the development of such prevalent diseases as diabetes, Alzheimer's disease, as well as mood disorders. GSK3 $\beta$ inhibitors can be classified into three categories: non-ATP-competitive, ATP-competitive, and substrate competitive inhibitors [69].

It has been demonstrated that non-ATP-competitive GSK3 $\beta$ inhibitors ameliorate depressive-like behavior in rodents. It has also been shown that prolonged learned helplessness is reversible and is maintained by abnormally active GSK3, whereas treatment with TDZD-8, non-ATP-competitive GSK3 inhibitor, reverses the impaired recovery from learned helplessness [70]. In turn, an ATP-competitive GSK3 $\beta$ inhibitor SB216763 has been found to increase anti-depressant responses in the forced swim test [71], whereas SAR502250 improved the stress-induced physical state in the chronic mild stress test in mice [72].

Intracerebroventricular injection of a novel GSK3 $\beta$ substrate competitive inhibitor, L803-mts, has reduced the duration of immobility in the forced swim test in mice, in comparison to control animals [73]. Additionally, the expression level of $\beta$-catenin, a substrate of GSK3 $\beta$, was increased in the inhibitor-treated animals [73].

The above studies demonstrate that GSK3 $\beta$ inhibitors produce anti-depressive-like behavior and suggest the potential of the kinase inhibitors as anti-depressants.

\subsection{BDNF-Regulated Action of GSK3 $\beta$}

In 1997, a reduction in the cortical volume of patients suffering from different types of depression was linked to decreased brain activity [74]. Since then, lowered cell density in PFC and decreased cortical thickness in patients with depression have been demonstrated [75]. Moreover, depressive behavior in rats is related to persistent remodeling of hippocampal synapses [76] and dendritic atrophy in hippocampi [77]. The decreased volume of the hippocampus has also been found in MDD patients in comparison to healthy individuals in an MRI-based study [78]. Similar effects are observed in rat and mouse medial PFC [79,80]. In contrast to the hippocampus and PFC, dendritic arborization and dendritic spines number are increased within limbic regions, such as nucleus accumbens and amygdala [81,82]. These changes are correlated with anxiety-like behavior and anhedonia [83]. Changes can also be observed in other brain regions, such as the ventral tegmental area [84]. Additionally, in the adult rodent brain, repeated stress reduces the neurogenesis ratio and the total neurons number in the dentate gyrus [85].

All the above changes might be linked to the altered activity of BDNF, a neurotrophic factor that supports the survival of existing neurons and improves the growth of new neurons and synapses [86]. 
However, the effect of BDNF on forebrain and mesolimbic circuitry during depressive episodes is heterogeneous. In a rat model of depression, the concentration of BDNF is reduced in the hippocampus [87], and the release of BDNF seems to mediate the rapid action of ketamine in PFC [88]. On the other hand, the levels of BDNF in structures of the mesolimbic system, such as nucleus accumbens and ventral tegmental area, are increased due to chronic stress [89], which promotes a pro-depressant phenotype. It corresponds to results of post mortem studies of human brains where an increased level of BDNF in nucleus accumbens has been detected [90].

The regulatory effect of BDNF on GSK3 $\beta$ activity is well characterized. BDNF is a ligand for tropomyosin receptor kinase $B(\operatorname{TrkB})$, the stimulation of which leads to the activation of PI3K/AKT and ERK1/2 signaling pathways [91]. Both of these pathways reduce the activity of GSK3 $\beta$, but only PI3K/AKT acts through phosphorylation of Ser9 [92,93]. Thus, factors influencing the BDNF level in the brain also impact GSK3 $\beta$ activity.

In contrast to the reduced level of BDNF in the PFC and hippocampus [87], the concentration of the factor is elevated in mesolimbic structures in depression [89]. Simultaneously, atrophy of the PFC and hippocampus, and increased synaptogenesis in limbic regions, are observed in depressed individuals $[75,77,81,82]$. This might be related to the BDNF-dependent GSK3 $\beta$ activity reduction. The Ser9 of GSK3 $\beta$ is highly phosphorylated upon stimulation of synaptogenesis, and the inhibition of the kinase is required for dendritic growth and arborization, whereas an increase in its activity leads to marked shrinkage of dendrites [94,95]. Moreover, in vivo overexpression of GSK3 $\beta$ reduces neurogenesis in adult hippocampus [96] and induces pro-depressant-like events [97].

One of the downstream targets of BDNF is p11 (also called S100A10), the expression of which is positively regulated by BDNF through TrkB and via the MAPK/ERK signaling pathway [98]. p11 is a calcium effector protein. It modulates signal transduction associated with serotonin receptors (especially $5-\mathrm{HT}_{1 \mathrm{~B}} \mathrm{R}$ ) stimulation [99] and increases plasma membrane localization of 5- $\mathrm{HT}_{1 \mathrm{~B}} \mathrm{Rs}$ [100]. p11 is downregulated in depressed patients [100], and overexpression of p11 has the anti-depressant-like effect [100]. Furthermore, p11 knockout mice exhibit a pro-depressant phenotype and are insensitive to the anti-depressant action of BDNF [98]. This might be correlated with a lowered amount of membrane-localized 5- $\mathrm{HT}_{1 \mathrm{~B}}$ Rs, which mediates inhibition GSK3 $\beta$ via AKT activation [34].

BDNF induces protein synthesis via activation of the mammalian target of rapamycin (mTOR), which can be inhibited by REDD1 (regulated in development and DNA damage response-1) protein. The expression of REDD1 is elevated in PFC due to chronic stress [101]. Post mortem studies of PFC tissue from patients suffering from depression have shown an increase in REDD1 [101] and a reduction in mTOR protein levels [102]. Phosphorylation of REDD1 leads to its proteasomal degradation and to the recovery of mTOR signaling [103]. Interestingly, REDD1 may be phosphorylated by GSK3 $\beta$, which triggers the recruitment of the E3 ligase complex and results in REDD1 ubiquitination and degradation by the proteasome [103]. This unexpected action of GSK3 in line with BDNF might be explained by the enhanced expression of ATF4 upon endoplasmic reticulum (ER) stress conditions. In such conditions, neuronal ATF4 can be upregulated (see below), which increases the expression of REDD1 [104] and simultaneously reduces GSK3 $\beta$ inhibition [105].

\subsection{GSK3 $\beta$ and the Unfolded Protein Response}

During the last years, several lines of evidence have demonstrated a strong connection between depression and unfolded protein response (UPR). UPR is a cellular stress response mechanism activated upon the accumulation of misfolded proteins in the ER. Activation of UPR leads to restoration of the ER homeostasis or if it cannot be achieved, to apoptosis [106]. The apoptosis is promoted by activation of the ATF4 and ATF6 transcription factors, which, in turn, induce expression of the pro-apoptotic C/EBP homologous protein (CHOP) [107,108].

The signs of ER-stress-induced UPR have been found in brains of depressed patients who died by suicide [109]. This strengthens the connection between depression and UPR. Moreover, UPR activation has been observed in several tauopathies, where the involvement of GSK3 $\beta$ in tau phosphorylation is 
well established [110]. As a result, the role of the kinase in ER-stress-induced UPR has been intensively investigated. Under stress conditions, the pro-apoptotic CHOP protein is regulated by GSK3. However, GSK3 inhibitors affect neither ATF4 nor ATF6 activity, which suggests that GSK3/CHOP interaction might be another ATF-independent factor in the life/death switch mediated by UPR [105]. In line with this, after UPR activation, the level of GSK3 $\beta$ phosphorylated on Ser9 is diminished [105].

It has been shown that UPR may be active also in mitochondria of the murine model of depression [111], which points to a new mechanism involved in the development of this disease.

Taking into account the results of the above studies, GSK3 appears to be strongly connected with the UPR, which is one of the potential causes of depression.

\section{5. $\beta$-Catenin Destruction Complex}

$\beta$-catenin, a multifunctional protein downstream to WNT signaling [112], is another factor putatively regulating stress resilience development [113]. WNT acts through membrane protein Frizzled and activates casein kinase 1 (CK1) and Disheveled (DSH). They, in turn, disrupt the so-called $\beta$-catenin destruction complex and activate $\beta$-catenin. This positively regulates the expression of WNT-related genes [46].

The $\beta$-catenin level is decreased in PFC tissue samples from MDD patients [41]. This is in line with an observation that overexpression of $\beta$-catenin mimics the effect of lithium [114]. GSK3 $\beta$ is a part of the $\beta$-catenin destruction complex, and its activity regulates $\beta$-catenin action. GSK $3 \beta$ phosphorylates and activates other members of the $\beta$-catenin destruction complex, axin, and adenomatous polyposis coli (APC). This results in GSK3 $\beta$-dependent phosphorylation of $\beta$-catenin and leads to its subsequent proteasomal degradation [115]. In the presence of the WNT signal, the activity of GSK3 $\beta$ is inhibited due to the disruption of the $\beta$-catenin destruction complex [46]. Additionally, upon WNT activation, a Frizzled-associated protein-low-density lipoprotein receptor-related protein 5 and 6 (LRP5/6), exposes its GSK $3 \beta$ pseudo-substrate motif (Pro-Pro-Pro-Ser-Pro-X-Ser) and inhibits GSK3 $\beta$ in a competitive manner [116].

\subsection{GSK3ß-miRNA Interaction}

$\beta$-catenin regulates the expression of various miRNA species, which play a role in neuroplasticity [117]. The first step of miRNA maturation occurs in the nucleus and engages the ribonuclease III enzyme called Drosha. GSK3 $\beta$ phosphorylates Drosha on Ser300 and Ser302 residues. This is required for the nuclear translocation of Drosha [118]. Inactivation of GSK3 $\beta$ results in the inhibition of maturation of the miR-302-367 cluster activated by WNT/ $\beta$-catenin signaling, and miR-181 family [119]. On the other hand, miR16 and miR135a downregulate GSK3 $\beta$ expression (according to Mouse Genome Informatics Scientific Curators, MGI Ref. ID J:208678). Both the miRs are decreased in the blood of MDD patients [120], which corresponds to an increased level of GSK3 $\beta$ [39]. Moreover, miR16 regulates the expression of 5-HT transporter (SERT) [121], while miR135a is associated with the regulation of the expression of SERT and 5- $\mathrm{HT}_{1 \mathrm{~A}} \mathrm{R}$ [122]. In MDD patients, the expression of miR135a increases after the implementation of anti-depressants (TCAs). This suggests the anti-depressant effect of miR135a [122].

\subsection{Role of GSK3 $\beta$ in DNA Methylation}

Some individuals suffering from MDD exhibit hyperactivity of the hypothalamic-pituitary-adrenal axis (HPA), which may be caused by increased production of the corticotrophin-releasing factor (CRF) [123]. An increased number of CRF-neurons has been found in the paraventricular nucleus of depressed patients [124]. CRF is probably involved in vulnerability to mood disorders in animal models of depression, which revealed a decreased methylation of CRF promoter upon social stressors [125]. Such a decrease in DNA methylation is in line with the altered expression of DNA methyltransferase 3a (DNMT3a) in the brain structures of depressed animals [126]. Moreover, an increased risk of suicide in humans is correlated with hyper-methylation of the BDNF promoter [127]. The expression of DNMT3a 
is regulated by c-Myc, a target of GSK3 $\beta$ [128]. The inhibition of GSK3 $\beta$ enhances the transcriptional activity of c-Myc. This upregulates the expression of DNMT3a [129]. Thus, the increased activity of GSK3 $\beta$ may be correlated with the lowered DNA methylation.

\subsection{Neuroinflammation in Depression}

Anti-inflammatory drugs may have anti-depressant effects in MDD patients $[130,131]$. Systemic injection of pro-inflammatory cytokines induces depression-like phenotype [132]. The elevated cytokine levels may be normalized by an anti-inflammatory treatment [133]. Depression-like behavior in rodents correlates with increased levels of pro-inflammatory cytokines: interleukin-1 $\beta$ (IL-1 $\beta$ ), interleukin-6 (IL-6), and tumor necrosis factor $\alpha(\mathrm{TNF} \alpha)$ [133,134], and decreased levels of anti-inflammatory interleukin-10 (IL-10) [135]. Nuclear factor $k$-light-chain-enhancer of activated B cells (NF-kB) promotes depression-like behaviors and inhibits neurogenesis in the hippocampus upon TNF $\alpha$ receptor (TNFR) and IL-1 receptor (IL-1R) activation due to chronic stress [136]. Elevated cytokine levels are accompanied by microglia activation/hyper-reactivity in PFC, cingulate cortex, and insula of depressed patients $[137,138]$. Pro-inflammatory cytokines, such as IL-6, can also be produced by astrocytes, and this can inhibit neurogenesis in the hippocampus [139]. On the other hand, cytokines alter astrocyte signaling, function, and amount. Post mortem studies have revealed a reduction in glial cell density in PFC, amygdala, and hippocampus of depressed patients [140]. This has been confirmed by studies showing decreased expression of the glial fibrillary acidic protein (GFAP, an astrocytic cell marker) in the PFC of depressed patients [141]. Astrocytic end feet, together with endothelial cells and pericytes, form the blood-brain barrier (BBB). Its integrity can be affected by malfunctions of astrocytes. This leads to increased permeability of the BBB and enhanced monocyte trafficking from the bloodstream to the central nervous system, which might strengthen the inflammatory reaction in the brain [142]. Additionally, it has been shown that IL-6 induces the production of inflammatory T helper 17 cells (Th17), thus increasing levels of these cells in the brain during depression-like states [143]. Moreover, it has been shown that the administration of Th17 cells promotes depression-like behaviors in mice, and inhibition of production and functioning of Th17 cells reduces the vulnerability of the animals to depression-like behavior [143].

NF- $\kappa B$ is a protein complex indispensable for the expression of inflammation-related genes and, thus, for the induction of inflammation. In unstimulated cells, NF- $\mathrm{KB}$ has cytosolic localization due to the activity of $I_{\kappa} B \alpha$ (nuclear factor of kappa light polypeptide gene enhancer in B-cells inhibitor, alpha) which binds to NF- $\mathrm{KB}$ and masks its nuclear localization signal [144]. Stimulation of TNFR and IL-1R activates I $\kappa B$ kinase (IKK), which inhibits I $\kappa B \alpha$. This leads to the translocation of NF- $k B$ to the nucleus, where it can act as a transcription factor [145].

The role of GSK3 $\beta$ in the modulation of the inflammatory response is as complex as the inflammatory transduction signal pathway itself [146].

The expression of IL-6 is regulated by a transcription factor STAT3 [147]. GSK3 $\beta$ promotes STAT3 activation and, thus, stimulates the expression of IL- 6 . Inhibition and knockdown of GSK3 $\beta$, but not GSK3 $\alpha$, strongly inhibits IL-6 production by glial cells both in vitro and in vivo [147].

GSK3 $\beta$ phosphorylates two members of NF-kB complex: p65 (RelA) and p105 (NF-kB1) $[148,149]$. This results in enhancement of the transactivation potential of p65 and prevents the proteasomal degradation of p105 in unstimulated cells [148]. However, upon TNF $\alpha$ stimulation, the GSK3-phosphorylated p105 undergoes subsequent phosphorylation by IKK, which leads to p105 degradation [148]. Thus, GSK3 $\beta$ plays a dual role in p105 stabilization, depending on whether or not the cells are stimulated. GSK3 $\beta$ also phosphorylates a transcriptional co-activator of NF- $\kappa B$ p50 homodimer: B-cell lymphoma 3-encoded protein (BCL-3) [148,149]. This leads to the degradation of BCL-3 and, therefore, the reduction in NF- $\mathrm{KB}$ activation [148]. Summarizing, GSK3 $\beta$ can either favor a rapid NF- $\mathrm{KB}$ activation or limit the activity of the factor. The effect of the kinase action depends on the activated pathway. 
Elevation of cytokines and chemokines levels in the hippocampi of mice displaying depression-like behavior is mediated by Toll-like receptor 4 (TLR4) activity [150]. It has been shown that the learned helplessness paradigm activates GSK3 in a wild-type mouse hippocampus, but not in TLR4 knockout mice [150]. Additionally, TDZD-8 attenuates an increased activation of NF- $\mathrm{KB}$ upon TLR4 stimulation [150], which indicates that GSK3 mediates a TLR4-related pro-inflammatory reaction associated with depression-like behavior.

It has been also demonstrated that BBB integrity disruption is partially mediated by TNF $\alpha$, and thus, it has been hypothesized that this factor contributes to blockade of the recovery from prolonged depression-like behavior [70]. An increased level of TNF $\alpha$ in non-recovered mice displaying depression-like behavior is accompanied by greater hippocampal activation of GSK3, higher levels of interleukin-17A and -23, and lower level of the BBB tight junction proteins in comparison to recovered and control animals [70]. The administration of TDZD-8 reduces inflammatory cytokines levels, increases tight junction proteins level, and reverses impaired recovery from depression-like behavior. Similar can be observed when a TNF $\alpha$ inhibitor, etanercept, is administrated. These observations indicate that the stress-induced GSK3 activation contributes to the disruption of BBB integrity mediated by pro-inflammatory factors, particularly TNF $\alpha$ [70].

It is worth noting that multiple research groups have reported that the manipulation of the gastrointestinal tract microbiome status affects anxiety- and depressive-like behaviors in rodents, and that the administration of probiotics reduces such behaviors [151]. The gut microbiota play an active role in immunity and inflammation [152]. However, it cannot be excluded that GSK3 $\beta$-regulated inflammatory reaction within the peripheral immune system is the place of origin of the inflammation-induced depression.

Thus, it can be concluded, that the deregulation of molecular pathways and cellular processes, such as neurotrophic factors-regulated, $\beta$-catenin-mediated, and inflammatory pathways, miRNAs expression, and DNA modification, observed during stress-induced conditions can be directly or indirectly linked with the malfunctioning of GSK3 $\beta$.

\section{DA and 5-HT/AKT/GSK3 Pathway Modulation and Its Behavioral Consequences}

DA regulates AKT/GSK3 pathway mainly in the $\beta$-arrestin 2-mediated manner. Urs et al. demonstrated that in mice, GSK3 $\beta$ knockout in D2R-expressing neurons, but not in D1R-expressing cells, mimics the action of antipsychotics [153]. The stabilization of $\beta$-catenin, a downstream target of GSK3 $\beta$, in D2R-positive neurons, does not affect mice behavior, which suggests that in this context, GSK3 $\beta$ does not act through the $\beta$-catenin-mediated pathway [153]. Constant hyper-dopaminergy in mice lacking DA transporter (DAT), which removes DA from the synaptic cleft, leads to a reduction in AKT activity and an increased activity of GSK3 $\alpha / \beta$ [154]. Additionally, the administration of DA receptor agonists, such as amphetamine, methamphetamine, or apomorphine, to normal mice results in AKT inhibition [155]. The depletion of DA has the opposite effect [156]. Hyper-dopaminergic mice display concomitant novelty-induced locomotor hyperactivity [157], which could be reduced by GSK3 inhibitors in the DAT lacking mice, and in amphetamine-treated normal mice [158,159]. Additionally, the inhibitory Ser9-phosphorylation of GSK3 $\beta$ is decreased in murine medial PFC after exposure of animals to novel objects, but the DAT knockdown mice exhibit no such decrease [160]. It has been found that the deletion of D3R in DAT knockdown mice restores novelty-induced GSK3 $\beta$ activation in the medial PFC. Moreover, inhibition or knockdown of GSK3 $\beta$, but not the $\alpha$ isozyme, in the medial PFC of wild-type mice impairs recognition memory [160], which suggests that in the medial PFC, D3R acts via GSK3 $\beta$ signaling to play a role in the novel objects recognition memory.

It has been demonstrated that $\mathrm{GSK}_{3} \beta^{+-}$heterozygotic mice are less responsive to amphetamine [158], whereas mice expressing a constitutively active GSK3 $\beta$ mutant develop a locomotor hyperactivity phenotype recapitulating the hyper-dopaminergy conditions [161].

The AKT/GSK3 $\beta$ pathway is also affected by 5-HT signaling. As has already been mentioned, 5-HT receptors play antagonistic roles in the regulation of GSK3 $\beta$ activity [13]. Loss-of-function 
mutation of tryptophan hydroxylase 2, a rate-limiting enzyme of neuronal 5-HT synthesis, causes a severe 5-HT deficiency and results in an increase in GSK3 activity in the frontal cortex [162]. It is accompanied by behavioral abnormalities in tests assessing 5-HT-mediated emotional states, such as anxiety and aggression, which can be reversed by the administration of a selective GSK3 $\beta$ inhibitor, TDZD-8 [162].

The presented data clearly demonstrate that the action of DA and 5-HT receptors is mediated by GSK3 $\beta$ and that the inhibition of the kinase can restore the effects of hyper-dopaminergy and hypo-serotoninergy.

\section{Influence of Anti-Depressants on GSK3 $\beta$ Activity}

A wide spectrum of currently used therapeutic agents in MDD treatment originates from the monoaminergic hypothesis of depression pathogenesis. However, the anti-depressant-like action of GSK3 $\beta$ inhibitors strongly suggests the involvement of this kinase in the pathogenesis of this disorder. Medicaments used in MDD treatment are summarized in Table 1.

Table 1. Main classes of medications currently used in major depressive disorder (MDD) treatment, with examples of their members and targets of their action. Trazodone, ketamine, and lithium do not belong to any of the listed groups.

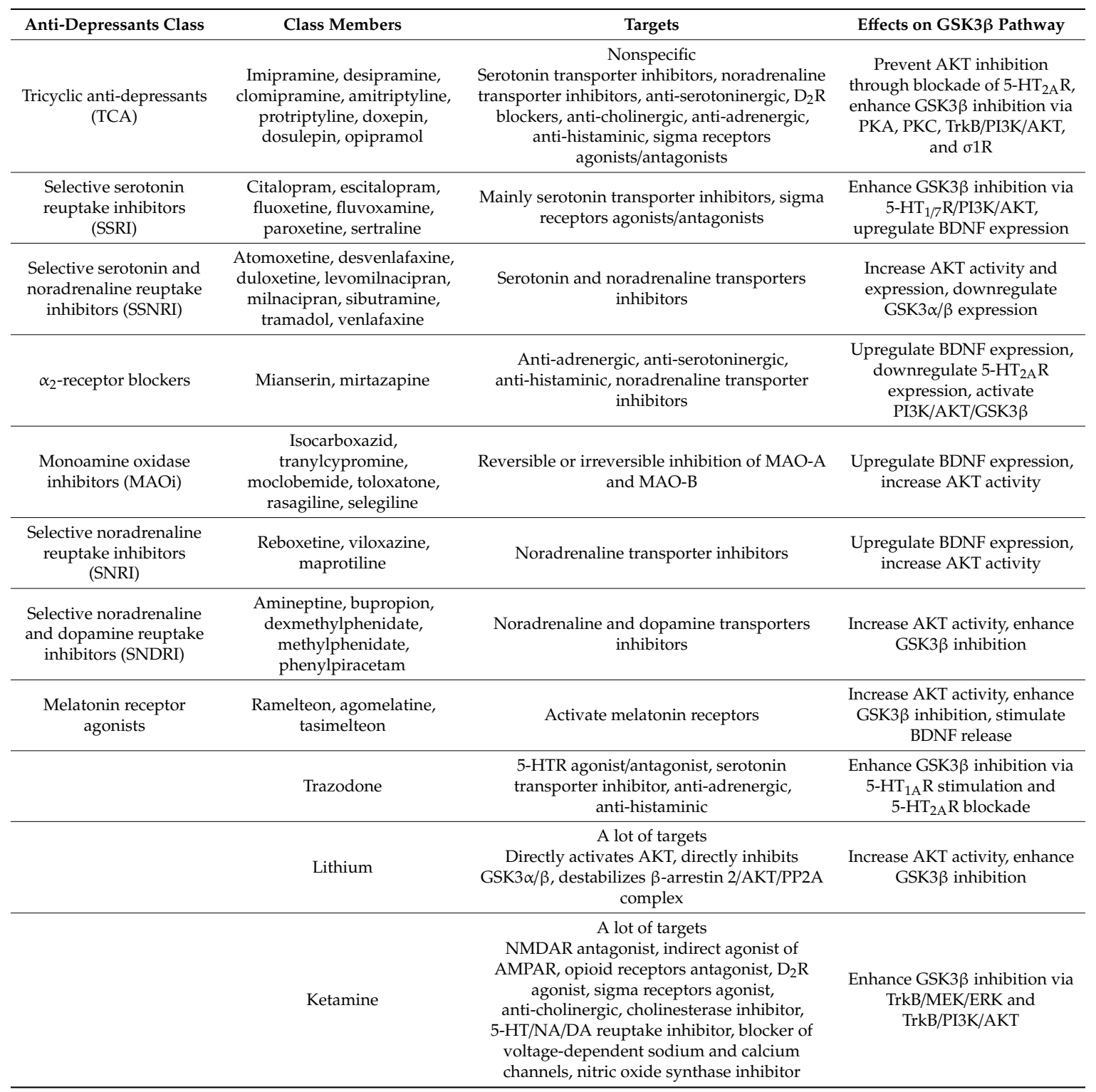




\subsection{Tricyclic Anti-Depressants}

Members of the Tricyclic anti-depressants (TCA) group are nonspecific agents acting on a wide range of neuronal receptors and monoamine transporters. The first described TCA is imipramine, which increases Ser9 phosphorylation of GSK3 $\beta$ in the mouse cerebral cortex, hippocampus, and striatum [163]. It is hypothesized that this effect is caused by the high affinity of imipramine binding to SERT, NA transporter (NET), and 5- $\mathrm{HT}_{2 \mathrm{~A}} \mathrm{R}$ (inhibition constants (Ki) are $1.3 \mathrm{nM}, 20-37 \mathrm{nM}$ [164], and 80-150 nM [165], respectively). NA acting through PKA and PKC [36,38], and 5-HT acting via receptors other than $5-\mathrm{HT}_{2 \mathrm{~A}} \mathrm{R}$ inactivate GSK3 $\beta$, whereas the blockade of $5-\mathrm{HT}_{2 \mathrm{~A}} \mathrm{R}$ prevents the inhibition of AKT [13]. A major metabolite of imipramine is desipramine, which has the highest affinity to NET (Ki 0.63-3.5 $\mathrm{nM} \mathrm{[164]).} \mathrm{One} \mathrm{week} \mathrm{of} \mathrm{desipramine} \mathrm{administration} \mathrm{significantly} \mathrm{lowers} \mathrm{the} \mathrm{expression} \mathrm{of}$ GSK3 $\beta$ gene in the mouse frontal cortex [166].

Another TCA, amitriptyline, which blocks SERT and NET (Ki 2.8-4.3 nM and 19-35 nM [164], respectively), enhances phosphorylation of the GSK3 $\beta$ Ser9 residue [167]. Moreover, amitriptyline acts as an agonist of TrkB in the absence of its ligands [168]. Activated TrkB regulates GSK3 $\beta$ via PI3K/AKT pathway [91].

To the best of our knowledge, an action of doxepin has not been studied in the context of GSK3 $\beta$ activity. However, it is known that chronic administration of doxepin does not alter AKT gene expression in rodent hippocampus $[169,170]$. On the other hand, in the rat model of Alzheimer's disease, doxepin reverses the effect of soluble amyloid $\beta$ 1-42-induced memory impairment acting through the PI3K/AKT/mTOR signaling pathway [171].

Among other TCAs, opipramol has the highest affinity to $\sigma$ opioid receptors (Ki for $\sigma 1$ receptor is about $0.2-50 \mathrm{nM}$ [172]) and acts as their agonist [173]. There is no literature data on the influence of opipramol on GSK3 $\beta$ activity. However, dehydroepiandrosterone, the most abundant neurosterol in the central nervous system, improves cognitive function, ameliorates depressive-like behaviors, and stimulates neurogenesis in the dentate gyrus, increasing the activity of AKT and phosphorylation of the GSK3 $\beta$ Ser9 residue via $\sigma 1$ receptors [174].

\subsection{Selective Serotonin Reuptake Inhibitors}

Therapeutic agents, such as citalopram, escitalopram, fluoxetine, fluvoxamine, paroxetine, and sertraline, belong to selective serotonin reuptake inhibitors (SSRIs). They increase concentrations of 5 -HT in the synaptic cleft by inhibiting SERT. They also act as agonists and antagonists of $\sigma 1$ receptors (only sertraline is a $\sigma 1$ receptor antagonist) [175].

Fluoxetine increases the inhibitory phosphorylation of GSK3 $\beta$ in mice hippocampi, and the anti-depressant effect of fluoxetine is diminished when the phosphorylation is hindered [176]. Citalopram and its (S)-stereoisomer escitalopram both stimulate the inhibitory phosphorylation of GSK3 $\beta[177,178]$. Furthermore, escitalopram upregulates AKT activity by Ser473 phosphorylation [178]. The same effect as fluvoxamine [179], whereas paroxetine inhibits GSK3 $\beta$ via functional synergism with FK506 binding protein 51 [180]. Additionally, SSRIs regulate BDNF gene expression, which could explain a requirement of several weeks of treatment to achieve the full therapeutic effect. Coppell et al. analyzed BDNF transcripts in rat hippocampi, after acute and chronic (14 days) administration of fluoxetine, paroxetine, and sertraline. They have found that $4 \mathrm{~h}$ after acute SSRI administration (the single injection) and $4 \mathrm{~h}$ after the last injection of the chronic treatment, BDNF gene expression level was significantly reduced in comparison to respective controls. Moreover, $24 \mathrm{~h}$ after the single injection, the BDNF expression level did not differ from control, whereas $24 \mathrm{~h}$ after the last injection of the chronic treatment, the expression level of BDNF was significantly higher than in control [181]. As BDNF is a major contributor to GSK3 $\beta$ activity regulation [91], factors which regulate its expression also influence GSK3 action.

The most elusive mechanism of action is attributed to sertraline. Besides its anti-depressant effect, sertraline has antiproliferative potential. In melanoma cells, sertraline downregulates AKT upregulating, thus GSK3 activity [182]. Additionally, in human breast adenocarcinoma, sertraline 
stimulates overexpression of REDD1 and inhibits mTOR [183]. Both AKT inhibition and REDD1 overexpression have been observed in depression $[53,101]$. However, in contrast to the depression-like effect of sertraline in cancer cells, its anti-depressant properties could be explained by the high affinity of sertraline to SERT (Ki is about $0.4 \mathrm{nM}$ [164]).

\subsection{Selective Serotonin and Noradrenaline Reuptake Inhibitors}

Selective serotonin and noradrenaline reuptake inhibitors (SSNRIs) increase amounts of 5-HT and NA in synaptic clefts by blocking SERT and NET. Members of the SSNRIs group, atomoxetine and milnacipran, induce AKT by increasing its activatory phosphorylation [184,185], whereas duloxetine stimulates expression of AKT and inhibits expression of both GSK3 isozymes [186].

\section{4. $\alpha 2$-Receptor Blockers}

Members of this group, mianserin and mirtazapine, besides their anti-adrenergic activity, can also block histaminergic $\mathrm{H} 1$ receptors and a wide spectrum of 5-HT receptors. Additionally, mianserin is a NET inhibitor [187]. Mirtazapine enhances BDNF gene expression in the cerebral cortex and hippocampus. It has been hypothesized that its effect is due to the activation of the PI3K/AKT pathway and inhibition of GSK3 $\beta$ [188]. Furthermore, the anti-depressant effect of mianserin and mirtazapine can be attributed to the downregulation of $5-\mathrm{HT}_{2 \mathrm{~A}} \mathrm{R}$ expression [189], which activates GSK3 $\beta$ via inhibition of AKT [190].

\subsection{Monoamine Oxidase Inhibitors}

Monoamine oxidase inhibitors (MAOi) reversibly or irreversibly inhibit the activity of both isozymes of monoamine oxidase, $\mathrm{A}$ and $\mathrm{B}$, thus increasing concentrations of 5-HT, adrenaline, NA, melatonin, and DA in the synaptic cleft. Tranylcypromine, a nonselective MAO-A and MAO-B inhibitor, enhances the activity of AKT and stimulates the expression of BDNF [191,192]. The elevated BDNF expression in the hippocampus, has also been demonstrated in moclobemide treatment [193]. Unfortunately, there are no data reporting a direct influence of MAOi on GSK3 $\beta$ activity.

\subsection{Selective Noradrenaline Reuptake Inhibitors}

Among many selective NET inhibitors, only reboxetine has been linked to GSK3 $\beta$ activity. It stimulates the overexpression of BDNF and the upregulation of AKT [192].

\subsection{Selective Noradrenaline and Dopamine Reuptake Inhibitors}

Inhibitors of NET and DAT are widely used in the treatment of depression, Parkinson's disease, and attention deficit hyperactivity disorder. However, only methylphenidate has been analyzed in the context of GSK3 $\beta$ activity. A chronic administration of methylphenidate increases activating phosphorylation of AKT and inhibits GSK3 $\beta$ in the cerebral cortex in mice [194].

\subsection{Melatonin Receptors Agonists}

Melatonin receptors are G-protein coupled receptors, which, in humans, occur in two types: MR1 and MR2. Their action is associated with modulation of PKA, PKC, and PLC activity. Melatonin increases the amount of Ser473-phosphorylated AKT and Ser9-phosphorylated GSK3 $\beta$ [195]. There are some melatonin receptors agonists, including ramelteon, agomelatine, and tasimelteon. Among them, agomelatine is suggested to stimulate the release of neuroprotective agents, such as BDNF, and act on the ERK/AKT/GSK3 $\beta$ signaling pathway. Agomelatine also acts as an antagonist of $5-\mathrm{HT}_{2 \mathrm{C}} \mathrm{R}$ [196].

\subsection{Trazodone}

The action of trazodone is complex. Besides its anti-adrenergic and anti-histaminic activity, trazodone is an agonist of $5-\mathrm{HT}_{1 \mathrm{~A}} \mathrm{R}$ and an antagonist of $5-\mathrm{HT}_{2 \mathrm{~A}} \mathrm{R}$. Moreover, trazodone acts as a weak 
inhibitor of SERT [197]. Trazodone slightly elevates the concentration of 5-HT in synaptic clefts and promotes AKT activity and GSK3 $\beta$ inactivation [197].

\subsection{Lithium}

Salts of lithium are used in the treatment of bipolar disorder and MDD. Lithium inhibits both isozymes of GSK3 directly [198] by competition with magnesium ions [199]. Lithium can also activate AKT and, thus, inhibit GSK3 indirectly $[158,200,201]$. The mechanism of the lithium-mediated AKT activation relies on the destabilization of the $\beta$-arrestin 2/AKT/PP2A complex in which AKT is dephosphorylated and inactivated [202].

\subsection{Ketamine}

Ketamine is an anesthetic that, in subanesthetic doses, demonstrates rapid-onset efficacy in patients with severe and treatment-refractory depression. Ketamine has a wide spectrum of effects, both immediate and delayed, on neuronal function, but its anti-depressant mechanism of action has not been well characterized yet. Ketamine can block the activity of NMDA receptors [203]. However, it also enhances glutamatergic transmission in the PFC and hippocampus [204]. It has been hypothesized that this paradox is a result of a much higher affinity of ketamine to NMDAR in GABAergic interneurons than to NMDAR in pyramidal neurons. The consequent ketamine-induced inhibition of the interneurons results in disinhibition of the pyramidal cells [205]. It might explain why, in high anesthetic doses, ketamine causes depression of the central nervous system, whereas its subanesthetic anti-depressant doses act depressively on inhibitory interneurons. Ketamine treatment leads to increased excitability of disinhibited glutamatergic neurons and may stimulate BDNF release [206]. The ketamine-induced BDNF release results in the activation of MAPK and ERK [207], downstream effectors of TrkB signaling. Ketamine also rapidly elevates the level of active AKT [204]. Both the TrkB/MEK/ERK and TrkB/PI3K/AKT pathways can activate mTOR and inactivate GSK3 $\beta[13,204]$. The activation of the former signaling pathway leads to an enhanced transcription of synaptic proteins, whereas stimulation of the latter pathway prevents internalization of AMPARs and shrinking of the synapse by the reduction in GSK3 $\beta$-mediated PSD95 phosphorylation [208]. It has been shown that inhibition of GSK3 is necessary for the rapid anti-depressant action of ketamine in mice [209], whereas knock-in mice with constitutively active GSK3 $\beta$ are insensitive to the anti-depressant action of ketamine [208].

\subsection{Electroconvulsive Therapy}

This kind of therapy is still widely used in the treatment of MDD, mania, and catatonia, especially in their treatment-resistant forms. Interestingly, acute electroconvulsive therapy has been found to increase the level of the Ser9-phosphorylated GSK3 $\beta$ in the murine frontal cortex and hippocampus [210].

Summarizing, it has been demonstrated that different classes of therapeutic used in the treatment of MDD act through the GSK3 $\beta$ pathway or affect the activity of the kinase directly or indirectly.

\section{Conclusions}

GSK3 $\beta$ activity and expression in a cell are regulated by a wide spectrum of neurotransmitters, neuromodulators, and neurotrophic factors. Many of them are targets of anti-depressant treatments. Thus, it is not surprising that such treatments also influence the activity of GSK3 $\beta$. Despite a variety of hypotheses considering potential factors and risks in the pathogenesis of MDD, nearly all of the hypotheses can be considered in the context of the GSK3 $\beta$ activity, which places the kinase at a central point of depression development and treatment. Abnormal GSK3 $\beta$ activity, an altered profile of its expression, and genetic polymorphism correlate with the MDD pathogenesis, age of its onset, and severity. However, further studies are needed to fully elucidate if the elevated activity of GSK3 $\beta$ is a reason or an effect of mood disorders. 
Author Contributions: P.D. conceptualized the study, wrote the original draft and prepared the figures and tables; D.H. and O.W. participated in the literature research and in the original draft writing; D.R. reviewed and edited the manuscript and figures, and A.G. wrote the final version of the manuscript and reviewed the figures. All authors have read and agreed to the published version of the manuscript.

Funding: The work was partially supported by the Polish Ministry of Science and Higher Education (Contract Grant Number: UMO-2015/19/B/NZ1/00332).

Conflicts of Interest: The authors declare no conflict of interest.

\section{References}

1. Malhi, G.S.; Mann, J.J. Depression. Lancet 2018, 392, 2299-2312. [CrossRef]

2. Kuhn, R. Treatment of depressive states with an iminodibenzyl derivative (G 22355). Schweiz. Med. Wochenschr. 1957, 87, 1135-1140. [PubMed]

3. Kline, N.S. Clinical experience with iproniazid (marsilid). J. Clin. Exp. Psychopathol. 1958, 19, 72-79. [PubMed]

4. Schildkraut, J.J. The catecholamine hypothesis of affective disorders: A review of supporting evidence. Am. J. Psychiatry 1965, 122, 509-522. [CrossRef]

5. Jelovac, A.; Kolshus, E.; McLoughlin, D.M. Relapse following successful electroconvulsive therapy for major depression: A meta-analysis. Neuropsychopharmacology 2013, 38, 2467-2474. [CrossRef]

6. Costemale-Lacoste, J.F.; Guilloux, J.P.; Gaillard, R. The role of GSK-3 in treatment-resistant depression and links with the pharmacological effects of lithium and ketamine: A review of the literature. Encephale 2016, 42, 156-164. [CrossRef]

7. Embi, N.; Rylatt, D.B.; Cohen, P. Glycogen synthase kinase-3 from rabbit skeletal muscle. Separation from cyclic-AMP-dependent protein kinase and phosphorylase kinase. Eur. J. Biochem. 1980, 107, 519-527. [CrossRef]

8. Yao, H.B.; Shaw, P.C.; Wong, C.C.; Wan, D.C.C. Expression of glycogen synthase kinase-3 isoforms in mouse tissues and their transcription in the brain. J. Chem. Neuroanat. 2002, 23, 291-297. [CrossRef]

9. Lau, K.F.; Miller, C.C.; Anderton, B.H.; Shaw, P.C. Expression analysis of glycogen synthase kinase-3 in human tissues. J. Pept. Res. 1999, 54, 85-91. [CrossRef]

10. Hughes, K.; Nikolakaki, E.; Plyte, S.E.; Totty, N.F.; Woodgett, J.R. Modulation of the glycogen synthase kinase-3 family by tyrosine phosphorylation. EMBO J. 1993, 12, 803-808. [CrossRef]

11. Stambolic, V.; Woodgett, J.R. Mitogen inactivation of glycogen synthase kinase-3 beta in intact cells via serine 9 phosphorylation. Biochem. J. 1994, 303, 701-704. [CrossRef] [PubMed]

12. Beurel, E.; Grieco, S.F.; Jope, R.S. Glycogen synthase kinase-3 (GSK3): Regulation, actions, and diseases. Pharmacol. Ther. 2015, 148, 114-131. [CrossRef] [PubMed]

13. Duda, P.; Wiśniewski, J.; Wójtowicz, T.; Wójcicka, O.; Jaśkiewicz, M.; Drulis-Fajdasz, D.; Rakus, D.; McCubrey, J.A.; Gizak, A. Targeting GSK3 signaling as a potential therapy of neurodegenerative diseases and aging. Expert Opin. Ther. Targets 2018, 22, 833-848. [CrossRef] [PubMed]

14. Manning, B.D.; Toker, A. AKT/PKB Signaling: Navigating the Network. Cell 2017, 169, 381-405. [CrossRef] [PubMed]

15. Hermida, M.A.; Dinesh, K.J.; Leslie, N.R. GSK3 and its interactions with the PI3K/AKT/mTOR signalling network. Adv. Biol. Regul. 2017, 65, 5-15. [CrossRef] [PubMed]

16. Vallée, A.; Lecarpentier, Y.; Guillevin, R.; Vallée, J. Interactions between TGF- $\beta 1$, canonical WNT/ $\beta$-catenin pathway and PPAR $\gamma$ in radiation-induced fibrosis. Oncotarget 2017, 8, 90579-90604. [CrossRef]

17. Nagini, S.; Sophia, J.; Mishra, R. Glycogen synthase kinases: Moonlighting proteins with theranostic potential in cancer. Semin. Cancer Biol. 2018, 56, 25-36. [CrossRef]

18. Eldar-Finkelman, H.; Seger, R.; Vandenheede, J.R.; Krebs, E.G. Inactivation of glycogen synthase kinase-3 by epidermal growth factor is mediated by mitogen-activated protein kinase/p90 ribosomal protein S6 kinase signaling pathway in NIH/3T3 cells. J. Biol. Chem. 1995, 270, 987-990. [CrossRef]

19. Thornton, T.M.; Pedraza-Alva, G.; Deng, B.; Wood, C.D.; Aronshtam, A.; Clements, J.L.; Sabio, G.; Davis, R.J.; Matthews, D.E.; Doble, B.; et al. Phosphorylation by p38 MAPK as an alternative pathway for GSK3beta inactivation. Science 2008, 320,667-670. [CrossRef] 
20. Fang, X.; Yu, S.X.; Lu, Y.; Bast, R.C.; Woodgett, J.R.; Mills, G.B. Phosphorylation and inactivation of glycogen synthase kinase 3 by protein kinase A. Proc. Natl. Acad. Sci. USA 2000, 97, 11960-11965. [CrossRef]

21. Wu, C.; Dedhar, S. Integrin-linked kinase (ILK) and its interactors: A new paradigm for the coupling of extracellular matrix to actin cytoskeleton and signaling complexes. J. Cell Biol. 2001, 155, 505-510. [CrossRef]

22. Song, B.; Lai, B.; Zheng, Z.; Zhang, Y.; Luo, J.; Wang, C.; Chen, Y.; Woodgett, J.R.; Li, M. Inhibitory Phosphorylation of GSK-3 by CaMKII Couples Depolarization to Neuronal Survival. J. Biol. Chem. 2010, 285, 41122-41134. [CrossRef] [PubMed]

23. Hernández, F.; Langa, E.; Cuadros, R.; Avila, J.; Villanueva, N. Regulation of GSK3 isoforms by phosphatases PP1 and PP2A. Mol. Cell Biochem. 2010, 344, 211-215. [CrossRef]

24. Luscher, C.; Malenka, R.C. NMDA Receptor-Dependent Long-Term Potentiation and Long-Term Depression (LTP/LTD). Cold Spring Harb. Perspect. Biol. 2012, 4, a005710. [CrossRef] [PubMed]

25. Li, L.; Stefan, M.I.; Le Novère, N. Calcium Input Frequency, Duration and Amplitude Differentially Modulate the Relative Activation of Calcineurin and CaMKII. PLOS ONE 2012, 7, e43810. [CrossRef]

26. Kim, Y.; Lee, Y.I.; Seo, M.; Kim, S.Y.; Lee, J.E.; Youn, H.D.; Kim, Y.S.; Juhnn, Y.S. Calcineurin dephosphorylates glycogen synthase kinase-3 beta at serine-9 in neuroblast-derived cells. J. Neurochem. 2009, 111, 344-354. [CrossRef] [PubMed]

27. Bats, C.; Groc, L.; Choquet, D. The Interaction between Stargazin and PSD-95 Regulates AMPA Receptor Surface Trafficking. Neuron 2007, 53, 719-734. [CrossRef]

28. Wei, J.; Liu, W.; Yan, Z. Regulation of AMPA receptor trafficking and function by glycogen synthase kinase 3. J. Biol. Chem. 2010, 285, 26369-26376. [CrossRef]

29. Choii, G.; Ko, J. Gephyrin: A central GABAergic synapse organizer. Exp. Mol. Med. 2015, 47, e158. [CrossRef]

30. Tyagarajan, S.K.; Ghosh, H.; Yevenes, G.E.; Nikonenko, I.; Ebeling, C.; Schwerdel, C.; Sidler, C.; Zeilhofer, H.U.; Gerrits, B.; Muller, D.; et al. Regulation of GABAergic synapse formation and plasticity by GSK3 $\beta$-dependent phosphorylation of gephyrin. Proc. Natl. Acad. Sci. USA 2011, 108, 379-384. [CrossRef]

31. Lu, F.F.; Su, P.; Liu, F.; Daskalakis, Z.J. Activation of GABA(B) receptors inhibits protein kinase B/glycogen synthase kinase 3 signaling. Mol. Brain 2012, 5, 41. [CrossRef] [PubMed]

32. Rangel-Barajas, C.; Coronel, I.; Florán, B. Dopamine Receptors and Neurodegeneration. Aging Dis. 2015, 6, 349-368. [CrossRef] [PubMed]

33. Beaulieu, J.M. A role for Akt and glycogen synthase kinase-3 as integrators of dopamine and serotonin neurotransmission in mental health. J. Psychiatry Neurosci. 2012, 37, 7-16. [CrossRef] [PubMed]

34. Li, X.; Zhu, W.; Roh, M.S.; Friedman, A.B.; Rosborough, K.; Jope, R.S. In vivo regulation of glycogen synthase kinase-3beta (GSK3beta) by serotonergic activity in mouse brain. Neuropsychopharmacology 2004, 29, 1426-1431. [CrossRef]

35. Polter, A.M.; Li, X. Glycogen Synthase Kinase-3 is an Intermediate Modulator of Serotonin Neurotransmission. Front. Mol. Neurosci. 2011, 4, 31. [CrossRef]

36. Ballou, L.M.; Tian, P.Y.; Lin, H.Y.; Jiang, Y.P.; Lin, R.Z. Dual Regulation of Glycogen Synthase Kinase-3 $\beta$ by the $\alpha_{1 \mathrm{~A}}$-Adrenergic Receptor. J. Biol. Chem. 2001, 276, 40910-40916. [CrossRef]

37. Xing, B.; Li, Y.C.; Gao, W.J. Norepinephrine versus dopamine and their interaction in modulating synaptic function in the prefrontal cortex. Brain Res. 2016, 1641, 217-233. [CrossRef]

38. Morioka, N.; Abe, H.; Araki, R.; Matsumoto, N.; Zhang, F.F.; Nakamura, Y.; Hisaoka-Nakashima, K.; Nakata, Y. A $\beta 1 / 2$ Adrenergic Receptor-Sensitive Intracellular Signaling Pathway Modulates CCL2 Production in Cultured Spinal Astrocytes. J. Cell Physiol. 2014, 229, 323-332. [CrossRef]

39. Jope, R.S. Glycogen Synthase Kinase-3 in the Etiology and Treatment of Mood Disorders. Front. Mol. Neurosci. 2011, 4, 16. [CrossRef]

40. Karege, F.; Perroud, N.; Burkhardt, S.; Schwald, M.; Ballmann, E.; La Harpe, R.; Malafosse, A. Alteration in Kinase Activity but Not in Protein Levels of Protein Kinase B and Glycogen Synthase Kinase-3 $\beta$ in Ventral Prefrontal Cortex of Depressed Suicide Victims. Biol. Psychiatry 2007, 61, 240-245. [CrossRef]

41. Karege, F.; Perroud, N.; Burkhardt, S.; Fernandez, R.; Ballmann, E.; La Harpe, R.; Malafosse, A. Protein levels of $\beta$-catenin and activation state of glycogen synthase kinase- $3 \beta$ in major depression. A study with postmortem prefrontal cortex. J. Affect. Disord. 2012, 136, 185-188. [CrossRef] [PubMed]

42. Diniz, B.S.; Talib, L.L.; Giroud, J.H.P.; de Paula, V.R.J.; Gattaz, W.F.; Forlenza, O.V. Platelet GSK3B activity in patients with late-life depression: Marker of depressive episode severity and cognitive impairment? World J. Biol. Psychiatry 2011, 12, 216-222. [CrossRef] [PubMed] 
43. Pláteník, J.; Fišar, Z.; Buchal, R.; Jirák, R.; Kitzlerová, E.; Zvěřová, M.; Raboch, J. GSK3ß, CREB, and BDNF in peripheral blood of patients with Alzheimer's disease and depression. Prog. Neuro-Psychopharmacology Biol. Psychiatry 2014, 50, 83-93. [CrossRef] [PubMed]

44. Alttoa, A.; Kõiv, K.; Hinsley, T.A.; Brass, A.; Harro, J. Differential gene expression in a rat model of depression based on persistent differences in exploratory activity. Eur. Neuropsychopharmacol 2010, 20, 288-300. [CrossRef]

45. Höflich, A.; Michenthaler, P.; Kasper, S.; Lanzenberger, R. Circuit Mechanisms of Reward, Anhedonia, and Depression. Int. J. Neuropsychopharmacol 2019, 22, 105-118. [CrossRef]

46. Wilkinson, M.B.; Dias, C.; Magida, J.; Mazei-Robison, M.; Lobo, M.; Kennedy, P.; Dietz, D.; Covington, H.; Russo, S.; Neve, R.; et al. A novel role of the WNT-dishevelled-GSK3 $\beta$ signaling cascade in the mouse nucleus accumbens in a social defeat model of depression. J. Neurosci. 2011, 31, 9084-9092. [CrossRef]

47. Crofton, E.J.; Nenov, M.N.; Zhang, Y.; Scala, F.; Page, S.A.; McCue, D.L.; Li, D.; Hommel, J.D.; Laezza, F.; Green, T.A. Glycogen synthase kinase 3 beta alters anxiety-, depression-, and addiction-related behaviors and neuronal activity in the nucleus accumbens shell. Neuropharmacology 2017, 117, 49-60. [CrossRef]

48. Crofton, E.J.; Zhang, Y.; Green, T.A. Inoculation stress hypothesis of environmental enrichment. Neurosci. Biobehav. Rev. 2015, 49, 19-31. [CrossRef]

49. Barik, J.; Marti, F.; Morel, C.; Fernandez, S.P.; Lanteri, C.; Godeheu, G.; Tassin, J.P.; Mombereau, C.; Faure, P.; Tronche, F. Chronic stress triggers social aversion via glucocorticoid receptor in dopaminoceptive neurons. Science 2013, 339, 332-335. [CrossRef]

50. Sugama, S.; Kakinuma, Y. Loss of dopaminergic neurons occurs in the ventral tegmental area and hypothalamus of rats following chronic stress: Possible pathogenetic loci for depression involved in Parkinson's disease. Neurosci. Res. 2016, 111, 48-55. [CrossRef]

51. Douma, E.H.; de Kloet, E.R. Stress-induced plasticity and functioning of ventral tegmental dopamine neurons. Neurosci. Biobehav. Rev. 2020, 108, 48-77. [CrossRef] [PubMed]

52. Li, S.X.; Wei, Y.M.; Shi, H.S.; Luo, Y.X.; Ding, Z.B.; Xue, Y.X.; Lu, L.; Yu, C.X. Glycogen synthase kinase-3 $\beta$ in the ventral tegmental area mediates diurnal variations in cocaine-induced conditioned place preference in rats. Addict. Biol. 2014, 19, 996-1005. [CrossRef] [PubMed]

53. Krishnan, V.; Han, M.H.; Mazei-Robison, M.; Iñiguez, S.D.; Ables, J.L.; Vialou, V.; Berton, O.; Ghose, S.; Covington, H.E.; Wiley, M.D.; et al. AKT Signaling within the Ventral Tegmental Area Regulates Cellular and Behavioral Responses to Stressful Stimuli. Biol. Psychiatry 2008, 64, 691-700. [CrossRef] [PubMed]

54. Zhang, K.; Yang, C.; Xu, Y.; Sun, N.; Yang, H.; Liu, J.; Xu, Q.; Shen, Y. Genetic association of the interaction between the BDNF and GSK3B genes and major depressive disorder in a Chinese population. J. Neural Transm. 2010, 117, 393-401. [CrossRef]

55. Yang, C.; Xu, Y.; Sun, N.; Ren, Y.; Liu, Z.; Cao, X.; Zhang, K. The combined effects of the BDNF and GSK3B genes modulate the relationship between negative life events and major depressive disorder. Brain Res. 2010, 1355, 1-6. [CrossRef]

56. Saus, E.; Soria, V.; Escaramís, G.; Crespo, J.M.; Valero, J.; Gutiérrez-Zotes, A.; Martorell, L.; Vilella, E.; Menchón, J.M.; Estivill, X.; et al. A haplotype of glycogen synthase kinase $3 \beta$ is associated with early onset of unipolar major depression. Genes Brain Behav. 2010, 9, 799-807. [CrossRef]

57. Kwok, J.B.J.; Hallupp, M.; Loy, C.T.; Chan, D.K.Y.; Woo, J.; Mellick, G.D.; Buchanan, D.D.; Silburn, P.A.; Halliday, G.M.; Schofield, P.R. GSK3B polymorphisms alter transcription and splicing in Parkinson's disease. Ann. Neurol. 2005, 58, 829-839. [CrossRef]

58. Inkster, B.; Nichols, T.E.; Saemann, P.G.; Auer, D.P.; Holsboer, F.; Muglia, P.; Matthews, P.M. Association of GSK3 $\beta$ Polymorphisms With Brain Structural Changes in Major Depressive Disorder. Arch. Gen. Psychiatry 2009, 66, 721-728. [CrossRef]

59. Liu, S.; Sun, N.; Xu, Y.; Yang, C.; Ren, Y.; Liu, Z.; Cao, X.; Sun, Y.; Xu, Q.; Zhang, K.; et al. Possible Association of the GSK3 $\beta$ Gene with the Anxiety Symptoms of Major Depressive Disorder and P300 Waveform. Genet. Test Mol. Biomarkers 2012, 16, 1382-1389. [CrossRef]

60. Levchenko, A.; Losenkov, I.S.; Vyalova, N.M.; Simutkin, G.G.; Bokhan, N.A.; Wilffert, B.; Loonen, A.J.; Ivanova, S.A. The functional variant rs334558 of GSK3B is associated with remission in patients with depressive disorders. Pharmgenomics Pers. Med. 2018, 11, 121-126. [CrossRef]

61. Berton, O.; Nestler, E.J. New approaches to antidepressant drug discovery: Beyond monoamines. Nat. Rev. Neurosci. 2006, 7, 137-151. [CrossRef] [PubMed] 
62. Cade, J.F. Lithium Salts in the Treatment of Psychotic Excitement. Aust. N. Z. J. Psychiatry 1982, 16, 129-133. [CrossRef] [PubMed]

63. Klein, P.S.; Melton, D.A. A molecular mechanism for the effect of lithium on development. Proc. Natl. Acad. Sci. USA 1996, 93, 8455-8459. [CrossRef] [PubMed]

64. Polter, A.; Beurel, E.; Yang, S.; Garner, R.; Song, L.; Miller, C.A.; Sweatt, J.D.; McMahon, L.; Bartolucci, A.A.; $\mathrm{Li}, \mathrm{X}$.; et al. Deficiency in the inhibitory serine-phosphorylation of glycogen synthase kinase-3 increases sensitivity to mood disturbances. Neuropsychopharmacology 2010, 35, 1761-1774. [CrossRef]

65. Pardo, M.; Abrial, E.; Jope, R.S.; Beurel, E. GSK3 $\beta$ isoform-selective regulation of depression, memory and hippocampal cell proliferation. Genes Brain Behav. 2016, 15, 348-355. [CrossRef]

66. Omata, N.; Chiu, C.T.; Moya, P.R.; Leng, Y.; Wang, Z.; Hunsberger, J.G.; Leeds, P.; Chuang, D.M. Lentivirally mediated GSK-3 $\beta$ silencing in the hippocampal dentate gyrus induces antidepressant-like effects in stressed mice. Int. J. Neuropsychopharmacol 2011, 14, 711-717. [CrossRef]

67. O’Brien, W.T.; Harper, A.D.; Jové, F.; Woodgett, J.R.; Maretto, S.; Piccolo, S.; Klein, P.S. Glycogen synthase kinase-3beta haploinsufficiency mimics the behavioral and molecular effects of lithium. J. Neurosci. 2004, 24, 6791-6798. [CrossRef]

68. O’Brien, W.T.; Huang, J.; Buccafusca, R.; Garskof, J.; Valvezan, A.J.; Berry, G.T.; Klein, P.S. Glycogen synthase kinase- 3 is essential for $\beta$-arrestin-2 complex formation and lithium-sensitive behaviors in mice. J. Clin. Invest. 2011, 121, 3756-3762. [CrossRef]

69. Khan, I.; Tantray, M.A.; Alam, M.S.; Hamid, H. Natural and synthetic bioactive inhibitors of glycogen synthase kinase. Eur. J. Med. Chem. 2017, 125, 464-477. [CrossRef]

70. Cheng, Y.; Desse, S.; Martinez, A.; Worthen, R.J.; Jope, R.S.; Beurel, E. TNF $\alpha$ disrupts blood brain barrier integrity to maintain prolonged depressive-like behavior in mice. Brain Behav. Immun. 2018, 69, 556-567. [CrossRef]

71. Liu, R.J.; Fuchikami, M.; Dwyer, J.M.; Lepack, A.E.; Duman, R.S.; Aghajanian, G.K. GSK-3 inhibition potentiates the synaptogenic and antidepressant-like effects of subthreshold doses of ketamine. Neuropsychopharmacology 2013, 38, 2268-2277. [CrossRef] [PubMed]

72. Griebel, G.; Stemmelin, J.; Lopez-Grancha, M.; Boulay, D.; Boquet, G.; Slowinski, F.; Pichat, P.; Beeské, S.; Tanaka, S.; Mori, A.; et al. The selective GSK3 inhibitor, SAR502250, displays neuroprotective activity and attenuates behavioral impairments in models of neuropsychiatric symptoms of Alzheimer's disease in rodents. Sci. Rep. 2019, 9, 18045. [CrossRef] [PubMed]

73. Kaidanovich-Beilin, O.; Milman, A.; Weizman, A.; Pick, C.G.; Eldar-Finkelman, H. Rapid antidepressive-like activity of specific glycogen synthase kinase- 3 inhibitor and its effect on $\beta$-catenin in mouse hippocampus. Biol. Psychiatry 2004, 55, 781-784. [CrossRef] [PubMed]

74. Drevets, W.C.; Price, J.L.; Simpson, J.R.; Todd, R.D.; Reich, T.; Vannier, M.; Raichle, M.E. Subgenual prefrontal cortex abnormalities in mood disorders. Nature 1997, 386, 824-827. [CrossRef]

75. Rajkowska, G.; Miguel-Hidalgo, J.J.; Wei, J.; Dilley, G.; Pittman, S.D.; Meltzer, H.Y.; Overholser, J.C.; Roth, B.L.; Stockmeier, C.A. Morphometric evidence for neuronal and glial prefrontal cell pathology in major depression. Biol. Psychiatry 1999, 45, 1085-1098. [CrossRef]

76. Hajszan, T.; Dow, A.; Warner-Schmidt, J.L.; Szigeti-Buck, K.; Sallam, N.L.; Parducz, A.; Leranth, C.; Duman, R.S. Remodeling of Hippocampal Spine Synapses in the Rat Learned Helplessness Model of Depression. Biol. Psychiatry 2009, 65, 392-400. [CrossRef]

77. Morales-Medina, J.C.; Juarez, I.; Venancio-García, E.; Cabrera, S.N.; Menard, C.; Yu, W.; Flores, G.; Mechawar, N.; Quirion, R. Impaired structural hippocampal plasticity is associated with emotional and memory deficits in the olfactory bulbectomized rat. Neuroscience 2013, 236, 233-243. [CrossRef]

78. Videbech, P.; Ravnkilde, B. Hippocampal volume and depression: A meta-analysis of MRI studies. Am. J. Psychiatry 2004, 161, 1957-1966. [CrossRef]

79. Radley, J.J.; Rocher, A.B.; Miller, M.; Janssen, W.G.M.; Liston, C.; Hof, P.R.; McEwen, B.S.; Morrison, J.H. Repeated Stress Induces Dendritic Spine Loss in the Rat Medial Prefrontal Cortex. Cereb. Cortex 2006, 16, 313-320. [CrossRef]

80. Izquierdo, A.; Wellman, C.L.; Holmes, A. Brief Uncontrollable Stress Causes Dendritic Retraction in Infralimbic Cortex and Resistance to Fear Extinction in Mice. J. Neurosci. 2006, 26, 5733-5738. [CrossRef]

81. Vyas, A.; Jadhav, S.; Chattarji, S. Prolonged behavioral stress enhances synaptic connectivity in the basolateral amygdala. Neuroscience 2006, 143, 387-393. [CrossRef] [PubMed] 
82. Warren, B.L.; Sial, O.K.; Alcantara, L.F.; Greenwood, M.A.; Brewer, J.S.; Rozofsky, J.P.; Parise, E.M.; Bolaños-Guzmán, C.A. Altered Gene Expression and Spine Density in Nucleus Accumbens of Adolescent and Adult Male Mice Exposed to Emotional and Physical Stress. Dev. Neurosci. 2014, 36, 250-260. [CrossRef] [PubMed]

83. Lim, B.K.; Huang, K.W.; Grueter, B.A.; Rothwell, P.E.; Malenka, R.C. Anhedonia requires MC4R-mediated synaptic adaptations in nucleus accumbens. Nature 2012, 487, 183-189. [CrossRef] [PubMed]

84. Ménard, C.; Hodes, G.E.; Russo, S.J. Pathogenesis of depression: Insights from human and rodent studies. Neuroscience 2016, 321, 138-162. [CrossRef]

85. Pham, K.; Nacher, J.; Hof, P.R.; McEwen, B.S. Repeated restraint stress suppresses neurogenesis and induces biphasic PSA-NCAM expression in the adult rat dentate gyrus. Eur. J. Neurosci. 2003, 17, 879-886. [CrossRef]

86. Yamada, K.; Nabeshima, T. Brain-derived neurotrophic factor/TrkB signaling in memory processes. J. Pharmacol. Sci. 2003, 91, 267-270. [CrossRef]

87. Aznar, S.; Klein, A.B.; Santini, M.A.; Knudsen, G.M.; Henn, F.; Gass, P.; Vollmayr, B. Aging and depression vulnerability interaction results in decreased serotonin innervation associated with reduced BDNF levels in hippocampus of rats bred for learned helplessness. Synapse 2010, 64, 561-565. [CrossRef]

88. Lepack, A.E.; Fuchikami, M.; Dwyer, J.M.; Banasr, M.; Duman, R.S. BDNF Release Is Required for the Behavioral Actions of Ketamine. Int. J. Neuropsychopharmacol 2015, 18, pyu033. [CrossRef]

89. Berton, O.; McClung, C.A.; Dileone, R.J.; Krishnan, V.; Renthal, W.; Russo, S.J.; Graham, D.; Tsankova, N.M.; Bolanos, C.A.; Rios, M.; et al. Essential Role of BDNF in the Mesolimbic Dopamine Pathway in Social Defeat Stress. Science 2006, 311, 864-868. [CrossRef]

90. Krishnan, V.; Han, M.H.; Graham, D.L.; Berton, O.; Renthal, W.; Russo, S.J.; LaPlant, Q.; Graham, A.; Lutter, M.; Lagace, D.C.; et al. Molecular Adaptations Underlying Susceptibility and Resistance to Social Defeat in Brain Reward Regions. Cell 2007, 131, 391-404. [CrossRef]

91. Mai, L.; Jope, R.S.; Li, X. BDNF-mediated signal transduction is modulated by GSK3beta and mood stabilizing agents. J. Neurochem. 2002, 82, 75-83. [CrossRef] [PubMed]

92. Cross, D.A.E.; Alessi, D.R.; Cohen, P.; Andjelkovich, M.; Hemmings, B.A. Inhibition of glycogen synthase kinase-3 by insulin mediated by protein kinase B. Nature 1995, 378, 785-789. [CrossRef] [PubMed]

93. Hetman, M.; Hsuan, S.L.; Habas, A.; Higgins, M.J.; Xia, Z. ERK1/2 Antagonizes Glycogen Synthase Kinase-3 $\beta$-induced Apoptosis in Cortical Neurons. J. Biol. Chem. 2002, 277, 49577-49584. [CrossRef] [PubMed]

94. Cuesto, G.; Jordán-Álvarez, S.; Enriquez-Barreto, L.; Ferrús, A.; Morales, M.; Acebes, Á. GSK3 $\beta$ Inhibition Promotes Synaptogenesis in Drosophila and Mammalian Neurons. PLoS ONE 2015, 10, e0118475. [CrossRef] [PubMed]

95. Rui, Y.; Myers, K.R.; Yu, K.; Wise, A.; De Blas, A.L.; Hartzell, H.C.; Zheng, J.Q. Activity-dependent regulation of dendritic growth and maintenance by glycogen synthase kinase 3ß. Nat. Commun. 2013, 4, 2628. [CrossRef] [PubMed]

96. Fuster-Matanzo, A.; Llorens-Martín, M.; Sirerol-Piquer, M.S.; García-Verdugo, J.M.; Avila, J.; Hernández, F. Dual effects of increased glycogen synthase kinase-3 $\beta$ activity on adult neurogenesis. Hum. Mol. Genet. 2013, 22, 1300-1315. [CrossRef]

97. Zhang, K.; Song, X.; Xu, Y.; Li, X.; Liu, P.; Sun, N.; Zhao, X.; Liu, Z.; Xie, Z.; Peng, J. Continuous GSK-3 $\beta$ overexpression in the hippocampal dentate gyrus induces prodepressant-like effects and increases sensitivity to chronic mild stress in mice. J. Affect. Disord. 2013, 146, 45-52. [CrossRef]

98. Warner-Schmidt, J.L.; Chen, E.Y.; Zhang, X.; Marshall, J.J.; Morozov, A.; Svenningsson, P.; Greengard, P. A role for p11 in the antidepressant action of brain-derived neurotrophic factor. Biol. Psychiatry 2010, 68, 528-535. [CrossRef]

99. Svenningsson, P.; Greengard, P. p11 (S100A10)—An inducible adaptor protein that modulates neuronal functions. Curr. Opin. Pharmacol. 2007, 7, 27-32. [CrossRef]

100. Svenningsson, P.; Chergui, K.; Rachleff, I.; Flajolet, M.; Zhang, X.; El Yacoubi, M.; Vaugeois, J.M.; Nomikos, G.G.; Greengard, P. Alterations in 5-HT1B Receptor Function by p11 in Depression-Like States. Science 2006, 311, 77-80. [CrossRef] [PubMed]

101. Ota, K.T.; Liu, R.J.; Voleti, B.; Maldonado-Aviles, J.G.; Duric, V.; Iwata, M.; Dutheil, S.; Duman, C.; Boikess, S.; Lewis, D.A.; et al. REDD1 is essential for stress-induced synaptic loss and depressive behavior. Nat. Med. 2014, 20, 531-535. [CrossRef] [PubMed] 
102. Jernigan, C.S.; Goswami, D.B.; Austin, M.C.; Iyo, A.H.; Chandran, A.; Stockmeier, C.A.; Karolewicz, B. The mTOR signaling pathway in the prefrontal cortex is compromised in major depressive disorder. Prog. Neuro-Psychopharmacology Biol. Psychiatry 2011, 35, 1774-1779. [CrossRef] [PubMed]

103. Katiyar, S.; Liu, E.; Knutzen, C.A.; Lang, E.S.; Lombardo, C.R.; Sankar, S.; Toth, J.I.; Petroski, M.D.; Ronai, Z.; Chiang, G.G. REDD1, an inhibitor of mTOR signalling, is regulated by the CUL4A-DDB1 ubiquitin ligase. EMBO Rep. 2009, 10, 866-872. [CrossRef] [PubMed]

104. Whitney, M.L.; Jefferson, L.S.; Kimball, S.R. ATF4 is necessary and sufficient for ER stress-induced upregulation of REDD1 expression. Biochem. Biophys. Res. Commun. 2009, 379, 451-455. [CrossRef]

105. Meares, G.P.; Mines, M.A.; Beurel, E.; Eom, T.Y.; Song, L.; Zmijewska, A.A.; Jope, R.S. Glycogen synthase kinase-3 regulates endoplasmic reticulum (ER) stress-induced CHOP expression in neuronal cells. Exp. Cell Res. 2011, 317, 1621-1628. [CrossRef]

106. Malhotra, J.D.; Kaufman, R.J. The endoplasmic reticulum and the unfolded protein response. Semin. Cell Dev. Biol. 2007, 18, 716-731. [CrossRef] [PubMed]

107. Timberlake, M., II; Dwivedi, Y. Linking unfolded protein response to inflammation and depression: Potential pathologic and therapeutic implications. Mol. Psychiatry 2019, 24, 987-994. [CrossRef]

108. Marciniak, S.J.; Yun, C.Y.; Oyadomari, S.; Novoa, I.; Zhang, Y.; Jungreis, R.; Nagata, K.; Harding, H.P.; Ron, D. $\mathrm{CHOP}$ induces death by promoting protein synthesis and oxidation in the stressed endoplasmic reticulum. Genes Dev. 2004, 18, 3066-3077. [CrossRef]

109. Bown, C.; Wang, J.F.; MacQueen, G.; Young, L.T. Increased Temporal Cortex ER Stress Proteins in Depressed Subjects Who Died by Suicide. Neuropsychopharmacology 2000, 22, 327-332. [CrossRef]

110. Nijholt, D.A.T.; Nölle, A.; van Haastert, E.S.; Edelijn, H.; Toonen, R.F.; Hoozemans, J.J.M.; Scheper, W. Unfolded protein response activates glycogen synthase kinase-3 via selective lysosomal degradation. Neurobiol. Aging 2013, 34, 1759-1771. [CrossRef]

111. Kambe, Y.; Miyata, A. Potential involvement of the mitochondrial unfolded protein response in depressive-like symptoms in mice. Neurosci. Lett. 2015, 588, 166-171. [CrossRef] [PubMed]

112. MacDonald, B.T.; Tamai, K.; He, X. Wnt/ $\beta$-Catenin Signaling: Components, Mechanisms, and Diseases. Dev. Cell 2009, 17, 9-26. [CrossRef] [PubMed]

113. Dias, C.; Feng, J.; Sun, H.; Shao, N.; Mazei-Robison, M.S.; Damez-Werno, D.; Scobie, K.; Bagot, R.; LaBonté, B.; Ribeiro, E.; et al. $\beta$-catenin mediates stress resilience through Dicer1/microRNA regulation. Nature 2014, 516, 51-55. [CrossRef] [PubMed]

114. Gould, T.D.; Einat, H.; O’Donnell, K.C.; Picchini, A.M.; Schloesser, R.J.; Manji, H.K. $\beta$-Catenin Overexpression in the Mouse Brain Phenocopies Lithium-Sensitive Behaviors. Neuropsychopharmacology 2007, 32, 2173-2183. [CrossRef]

115. Kimelman, D.; Xu, W. $\beta$-Catenin destruction complex: Insights and questions from a structural perspective. Oncogene 2006, 25, 7482-7491. [CrossRef]

116. Metcalfe, C.; Bienz, M. Inhibition of GSK3 by Wnt signalling-Two contrasting models. J. Cell Sci. 2011, 124, 3537-3544. [CrossRef]

117. Im, H.I.; Kenny, P.J. MicroRNAs in neuronal function and dysfunction. Trends Neurosci. 2012, 35, 325-334. [CrossRef]

118. Tang, X.; Li, M.; Tucker, L.; Ramratnam, B. Glycogen Synthase Kinase 3 Beta (GSK3 $\beta$ ) Phosphorylates the RNAase III Enzyme Drosha at S300 and S302. PLoS ONE 2011, 6, e20391. [CrossRef]

119. Wu, Y.; Liu, F.; Liu, Y.; Liu, X.; Ai, Z.; Guo, Z.; Zhang, Y. GSK3 inhibitors CHIR99021 and 6-bromoindirubin-3'-oxime inhibit microRNA maturation in mouse embryonic stem cells. Sci. Rep. 2015, 5, 8666. [CrossRef]

120. Gheysarzadeh, A.; Sadeghifard, N.; Afraidooni, L.; Pooyan, F.; Mofid, M.R.; Valadbeigi, H.; Bakhtiari, H.; Keikhavani, S. Serum-based microRNA biomarkers for major depression: MiR-16, miR-135a, and miR-1202. J. Res. Med. Sci. 2018, 23, 69. [CrossRef]

121. Baudry, A.; Mouillet-Richard, S.; Schneider, B.; Launay, J.M.; Kellermann, O. miR-16 targets the serotonin transporter: A new facet for adaptive responses to antidepressants. Science 2010, 329, 1537-1541. [CrossRef]

122. Issler, O.; Haramati, S.; Paul, E.D.; Maeno, H.; Navon, I.; Zwang, R.; Gil, S.; Mayberg, H.S.; Dunlop, B.W.; Menke, A.; et al. MicroRNA 135 is essential for chronic stress resiliency, antidepressant efficacy, and intact serotonergic activity. Neuron 2014, 83, 344-360. [CrossRef] [PubMed] 
123. Arborelius, L.; Owens, M.J.; Plotsky, P.M.; Nemeroff, C.B. The role of corticotropin-releasing factor in depression and anxiety disorders. J. Endocrinol. 1999, 160,1-12. [CrossRef] [PubMed]

124. Raadsheer, F.C.; Hoogendijk, W.J.G.; Stam, F.C.; Tilders, F.J.H.; Swaab, D.F. Increased Numbers of Corticotropin-Releasing Hormone Expressing Neurons in the Hypothalamic Paraventricular Nucleus of Depressed Patients. Neuroendocrinology 1994, 60, 436-444. [CrossRef] [PubMed]

125. Elliott, E.; Ezra-Nevo, G.; Regev, L.; Neufeld-Cohen, A.; Chen, A. Resilience to social stress coincides with functional DNA methylation of the Crf gene in adult mice. Nat. Neurosci. 2010, 13, 1351-1353. [CrossRef] [PubMed]

126. LaPlant, Q.; Vialou, V.; Covington, H.E.; Dumitriu, D.; Feng, J.; Warren, B.L.; Maze, I.; Dietz, D.M.; Watts, E.L.; Iñiguez, S.D.; et al. Dnmt3a regulates emotional behavior and spine plasticity in the nucleus accumbens. Nat. Neurosci. 2010, 13, 1137-1143. [CrossRef] [PubMed]

127. Kang, H.J.; Kim, J.M.; Lee, J.Y.; Kim, S.Y.; Bae, K.Y.; Kim, S.W.; Shin, I.S.; Kim, H.R.; Shin, M.G.; Yoon, J.S. BDNF promoter methylation and suicidal behavior in depressive patients. J. Affect. Disord. 2013, 151, 679-685. [CrossRef]

128. Sutherland, C. What Are the bona fide GSK3 Substrates? Int. J. Alzheimers Dis. 2011, 2011, 505607.

129. Pyko, I.V.; Nakada, M.; Sabit, H.; Teng, L.; Furuyama, N.; Hayashi, Y.; Kawakami, K.; Minamoto, T.; Fedulau, A.S.; Hamada, J. Glycogen synthase kinase $3 \beta$ inhibition sensitizes human glioblastoma cells to temozolomide by affecting $\mathrm{O} 6$-methylguanine DNA methyltransferase promoter methylation via c-Myc signaling. Carcinogenesis 2013, 34, 2206-2217. [CrossRef]

130. Raison, C.L.; Rutherford, R.E.; Woolwine, B.J.; Shuo, C.; Schettler, P.; Drake, D.F.; Haroon, E.; Miller, A.H. A Randomized Controlled Trial of the Tumor Necrosis Factor Antagonist Infliximab for Treatment-Resistant Depression. JAMA Psychiatry 2013, 70, 31. [CrossRef]

131. Köhler, O.; Benros, M.E.; Nordentoft, M.; Farkouh, M.E.; Iyengar, R.L.; Mors, O.; Krogh, J. Effect of Anti-inflammatory Treatment on Depression, Depressive Symptoms, and Adverse Effects. JAMA Psychiatry 2014, 71, 1381-1391. [CrossRef] [PubMed]

132. Dantzer, R.; O'Connor, J.C.; Freund, G.G.; Johnson, R.W.; Kelley, K.W. From inflammation to sickness and depression: When the immune system subjugates the brain. Nat. Rev. Neurosci. 2008, 9, 46-56. [CrossRef] [PubMed]

133. Kubera, M.; Obuchowicz, E.; Goehler, L.; Brzeszcz, J.; Maes, M. In animal models, psychosocial stress-induced (neuro)inflammation, apoptosis and reduced neurogenesis are associated to the onset of depression. Prog. Neuro-Psychopharmacology Biol. Psychiatry 2011, 35, 744-759. [CrossRef] [PubMed]

134. Hodes, G.E.; Pfau, M.L.; Leboeuf, M.; Golden, S.A.; Christoffel, D.J.; Bregman, D.; Rebusi, N.; Heshmati, M.; Aleyasin, H.; Warren, B.L.; et al. Individual differences in the peripheral immune system promote resilience versus susceptibility to social stress. Proc. Natl. Acad. Sci. USA 2014, 111, 16136-16141. [CrossRef] [PubMed]

135. Voorhees, J.L.; Tarr, A.J.; Wohleb, E.S.; Godbout, J.P.; Mo, X.; Sheridan, J.F.; Eubank, T.D.; Marsh, C.B. Prolonged Restraint Stress Increases IL-6, Reduces IL-10, and Causes Persistent Depressive-Like Behavior That Is Reversed by Recombinant IL-10. PLoS ONE 2013, 8, e58488. [CrossRef] [PubMed]

136. Koo, J.W.; Russo, S.J.; Ferguson, D.; Nestler, E.J.; Duman, R.S. Nuclear factor- B is a critical mediator of stress-impaired neurogenesis and depressive behavior. Proc. Natl. Acad. Sci. USA 2010, 107, 2669-2674. [CrossRef] [PubMed]

137. Steiner, J.; Walter, M.; Gos, T.; Guillemin, G.J.; Bernstein, H.G.; Sarnyai, Z.; Mawrin, C.; Brisch, R.; Bielau, H.; zu Schwabedissen, L.; et al. Severe depression is associated with increased microglial quinolinic acid in subregions of the anterior cingulate gyrus: Evidence for an immune-modulated glutamatergic neurotransmission? J. Neuroinflammation 2011, 8, 94. [CrossRef]

138. Setiawan, E.; Wilson, A.A.; Mizrahi, R.; Rusjan, P.M.; Miler, L.; Rajkowska, G.; Suridjan, I.; Kennedy, J.L.; Rekkas, P.V.; Houle, S.; et al. Role of Translocator Protein Density, a Marker of Neuroinflammation, in the Brain During Major Depressive Episodes. JAMA Psychiatry 2015, 72, 268. [CrossRef]

139. Vallières, L.; Campbell, I.L.; Gage, F.H.; Sawchenko, P.E. Reduced hippocampal neurogenesis in adult transgenic mice with chronic astrocytic production of interleukin-6. J. Neurosci. 2002, 22, 486-492. [CrossRef]

140. Russo, S.J.; Nestler, E.J. The brain reward circuitry in mood disorders. Nat. Rev. Neurosci. 2013, 14, 609-625. [CrossRef] 
141. Nagy, C.; Suderman, M.; Yang, J.; Szyf, M.; Mechawar, N.; Ernst, C.; Turecki, G. Astrocytic abnormalities and global DNA methylation patterns in depression and suicide. Mol. Psychiatry 2015, 20, 320-328. [CrossRef] [PubMed]

142. Wohleb, E.S.; McKim, D.B.; Shea, D.T.; Powell, N.D.; Tarr, A.J.; Sheridan, J.F.; Godbout, J.P. Re-establishment of Anxiety in Stress-Sensitized Mice Is Caused by Monocyte Trafficking from the Spleen to the Brain. Biol. Psychiatry 2014, 75, 970-981. [CrossRef] [PubMed]

143. Beurel, E.; Harrington, L.E.; Jope, R.S. Inflammatory T helper 17 cells promote depression-like behavior in mice. Biol. Psychiatry 2013, 73, 622-630. [CrossRef] [PubMed]

144. Jacobs, M.D.; Harrison, S.C. Structure of an IkappaBalpha/NF-kappaB complex. Cell 1998, 95, 749-758. [CrossRef]

145. Karin, M. How NF-кB is activated: The role of the IкB kinase (IKK) complex. Oncogene 1999, 18, 6867-6874. [CrossRef]

146. Cortés-Vieyra, R.; Bravo-Patiño, A.; Valdez-Alarcón, J.J.; Juárez, M.C.; Finlay, B.B.; Baizabal-Aguirre, V.M. Role of glycogen synthase kinase- 3 beta in the inflammatory response caused by bacterial pathogens. $J$. Inflamm. 2012, 9, 23. [CrossRef]

147. Beurel, E.; Jope, R.S. Lipopolysaccharide-induced interleukin-6 production is controlled by glycogen synthase kinase-3 and STAT3 in the brain. J. Neuroinflammation 2009, 6, 9. [CrossRef]

148. Viatour, P.; Merville, M.P.; Bours, V.; Chariot, A. Phosphorylation of NF-kappaB and IkappaB proteins: Implications in cancer and inflammation. Trends Biochem. Sci. 2005, 30, 43-52. [CrossRef]

149. Ghosh, S.; Hayden, M.S. New regulators of NF-kB in inflammation. Nat. Rev. Immunol. 2008, 8, 837-848. [CrossRef]

150. Cheng, Y.; Pardo, M.; Armini, R.S.; Martinez, A.; Mouhsine, H.; Zagury, J.F.; Jope, R.S.; Beurel, E. Stress-induced neuroinflammation is mediated by GSK3-dependent TLR4 signaling that promotes susceptibility to depression-like behavior. Brain Behav. Immun. 2016, 53, 207-222. [CrossRef]

151. Foster, J.; McVey Neufeld, K.A. Gut-brain axis: How the microbiome influences anxiety and depression. Trends Neurosci. 2013, 36, 305-312. [CrossRef] [PubMed]

152. Kamada, N.; Seo, S.U.; Chen, G.Y.; Núñez, G. Role of the gut microbiota in immunity and inflammatory disease. Nat. Rev. Immunol. 2013, 13, 321-335. [CrossRef] [PubMed]

153. Urs, N.M.; Snyder, J.C.; Jacobsen, J.P.R.; Peterson, S.M.; Caron, M.G. Deletion of GSK3 $\beta$ in D2R-expressing neurons reveals distinct roles for $\beta$-arrestin signaling in antipsychotic and lithium action. Proc. Natl. Acad. Sci. USA 2012, 109, 20732-20737. [CrossRef] [PubMed]

154. Beaulieu, J.M.; Sotnikova, T.D.; Gainetdinov, R.R.; Caron, M.G. Paradoxical Striatal Cellular Signaling Responses to Psychostimulants in Hyperactive Mice. J. Biol. Chem. 2006, 281, 32072-32080. [CrossRef] [PubMed]

155. Chen, P.C.; Lao, C.L.; Chen, J.C. Dual alteration of limbic dopamine $\mathrm{D}_{1}$ receptor-mediated signalling and the Akt/GSK3 pathway in dopamine $\mathrm{D}_{3}$ receptor mutants during the development of methamphetamine sensitization. J. Neurochem. 2007, 100, 225-241. [CrossRef]

156. Bychkov, E.; Ahmed, M.R.; Dalby, K.N.; Gurevich, E.V. Dopamine depletion and subsequent treatment with 1-DOPA, but not the long-lived dopamine agonist pergolide, enhances activity of the Akt pathway in the rat striatum. J. Neurochem. 2007, 102, 699-711. [CrossRef]

157. Beaulieu, J.M.; Sotnikova, T.D.; Marion, S.; Lefkowitz, R.J.; Gainetdinov, R.R.; Caron, M.G. An Akt/ $\beta$-Arrestin 2/PP2A Signaling Complex Mediates Dopaminergic Neurotransmission and Behavior. Cell 2005, 122, 261-273. [CrossRef]

158. Beaulieu, J.M.; Sotnikova, T.D.; Yao, W.D.; Kockeritz, L.; Woodgett, J.R.; Gainetdinov, R.R.; Caron, M.G. Lithium antagonizes dopamine-dependent behaviors mediated by an AKT/glycogen synthase kinase 3 signaling cascade. Proc. Natl. Acad. Sci. USA 2004, 101, 5099-5104. [CrossRef]

159. Gould, T.D.; Einat, H.; Bhat, R.; Manji, H.K. AR-A014418, a selective GSK-3 inhibitor, produces antidepressant-like effects in the forced swim test. Int. J. Neuropsychopharmacol 2004, 7, 387-390. [CrossRef]

160. Chang, P.K.; Chu, J.; Tsai, Y.T.; Lai, Y.H.; Chen, J.C. Dopamine D3 receptor and GSK3 $\beta$ signaling mediate deficits in novel object recognition memory within dopamine transporter knockdown mice. J. Biomed. Sci. 2020, 27, 16. [CrossRef] 
161. Prickaerts, J.; Moechars, D.; Cryns, K.; Lenaerts, I.; van Craenendonck, H.; Goris, I.; Daneels, G.; Bouwknecht, J.A.; Steckler, T. Transgenic Mice Overexpressing Glycogen Synthase Kinase 3beta: A Putative Model of Hyperactivity and Mania. J. Neurosci. 2006, 26, 9022-9029. [CrossRef] [PubMed]

162. Beaulieu, J.M.; Zhang, X.; Rodriguiz, R.M.; Sotnikova, T.D.; Cools, M.J.; Wetsel, W.C.; Gainetdinov, R.R.; Caron, M.G. Role of GSK3 beta in behavioral abnormalities induced by serotonin deficiency. Proc. Natl. Acad. Sci. USA 2008, 105, 1333-1338. [CrossRef] [PubMed]

163. Roh, M.S.; Eom, T.Y.; Zmijewska, A.A.; De Sarno, P.; Roth, K.A.; Jope, R.S. Hypoxia activates glycogen synthase kinase- 3 in mouse brain in vivo: Protection by mood stabilizers and imipramine. Biol. Psychiatry 2005, 57, 278-286. [CrossRef] [PubMed]

164. Tatsumi, M.; Groshan, K.; Blakely, R.D.; Richelson, E. Pharmacological profile of antidepressants and related compounds at human monoamine transporters. Eur. J. Pharmacol. 1997, 340, 249-258. [CrossRef]

165. Cusack, B.; Nelson, A.; Richelson, E. Binding of antidepressants to human brain receptors: Focus on newer generation compounds. Psychopharmacology 1994, 114, 559-565. [CrossRef] [PubMed]

166. Solich, J.; Kolasa, M.; Kuśmider, M.; Faron-Górecka, A.; Pabian, P.; Szafran, K.; Żurawek, D.; Dziedzicka-Wasylewska, M. Effect of desipramine on gene expression in the mouse frontal cortex-Microarray study. Pharm. Rep. 2015, 67, 345-348. [CrossRef]

167. Cong, W.N.; Chadwick, W.; Wang, R.; Daimon, C.M.; Cai, H.; Amma, J.; Wood, W.H.; Becker, K.G.; Martin, B.; Maudsley, S. Amitriptyline Improves Motor Function via Enhanced Neurotrophin Signaling and Mitochondrial Functions in the Murine N171-82Q Huntington Disease Model. J. Biol. Chem. 2015, 290, 2728-2743. [CrossRef]

168. Jang, S.W.; Liu, X.; Chan, C.B.; Weinshenker, D.; Hall, R.A.; Xiao, G.; Ye, K. Amitriptyline is a TrkA and TrkB Receptor Agonist that Promotes TrkA/TrkB Heterodimerization and Has Potent Neurotrophic Activity. Chem. Biol. 2009, 16, 644-656. [CrossRef]

169. Reisi, P.; Eidelkhani, N.; Rafiee, L.; Kazemi, M.; Radahmadi, M.; Alaei, H. Effects of doxepin on gene expressions of Bcl-2 family, TNF- $\alpha$, MAP kinase 14, and Akt1 in the hippocampus of rats exposed to stress. Res. Pharm. Sci. 2017, 12, 15. [CrossRef]

170. Eidelkhani, N.; Radahmadi, M.; Kazemi, M.; Rafiee, L.; Alaei, H.; Reisi, P. Effects of doxepin on brain-derived neurotrophic factor, tumor necrosis factor alpha, mitogen-activated protein kinase 14, and AKT1 genes expression in rat hippocampus. Adv. Biomed. Res. 2015, 4, 203.

171. Bu, J.; $\mathrm{Zu}, \mathrm{H}$. Mechanism underlying the effects of doxepin on $\beta$-amyloid -induced memory impairment in rats. Iran J. Basic Med. Sci. 2017, 20, 1044-1049. [PubMed]

172. Rao, T.; Cler, J.; Mick, S.; Dilworth, V.; Contrepas, P.; Iyengar, S.; Wood, P. Neurochemical characterization of dopaminergic effects of opipramol, a potent sigma receptor ligand, in vivo. Neuropharmacology 1990, 29, 1191-1197. [CrossRef]

173. Möller, H.J.; Volz, H.P.; Reimann, I.W.; Stoll, K.D. Opipramol for the treatment of generalized anxiety disorder: A placebo-controlled trial including an alprazolam-treated group. J. Clin. Psychopharmacol. 2001, 21, 59-65. [CrossRef] [PubMed]

174. Moriguchi, S.; Shinoda, Y.; Yamamoto, Y.; Sasaki, Y.; Miyajima, K.; Tagashira, H.; Fukunaga, K. Stimulation of the Sigma-1 Receptor by DHEA Enhances Synaptic Efficacy and Neurogenesis in the Hippocampal Dentate Gyrus of Olfactory Bulbectomized Mice. PLoS ONE 2013, 8, e60863. [CrossRef]

175. Albayrak, Y.; Hashimoto, K. Sigma-1 Receptor Agonists and Their Clinical Implications in Neuropsychiatric Disorders. Adv. Exp. Med. Biol. 2017, 964, 153-161.

176. Polter, A.M.; Yang, S.; Jope, R.S.; Li, X. Functional significance of glycogen synthase kinase-3 regulation by serotonin. Cell. Signal. 2012, 24, 265-271. [CrossRef]

177. Chen, Y.C.; Tan, Q.R.; Dang, W.; Wang, H.N.; Zhang, R.B.; Li, Z.Y.; Lin, H.; Liu, R. The effect of citalopram on chronic stress-induced depressive-like behavior in rats through GSK3 $\beta / \beta$-catenin activation in the medial prefrontal cortex. Brain Res. Bull. 2012, 88, 338-344. [CrossRef]

178. Ren, Q.G.; Wang, Y.J.; Gong, W.G.; Xu, L.; Zhang, Z.J. Escitalopram Ameliorates Tau Hyperphosphorylation and Spatial Memory Deficits Induced by Protein Kinase A Activation in Sprague Dawley Rats. J. Alzheimer's Dis. 2015, 47, 61-71. [CrossRef]

179. Muneer, A. Wnt and GSK3 Signaling Pathways in Bipolar Disorder: Clinical and Therapeutic Implications. Clin. Psychopharmacol. Neurosci. 2017, 15, 100. [CrossRef] 
180. Gassen, N.C.; Hartmann, J.; Zannas, A.S.; Kretzschmar, A.; Zschocke, J.; Maccarrone, G.; Hafner, K.; Zellner, A.; Kollmannsberger, L.K.; Wagner, K.V.; et al. FKBP51 inhibits GSK3 $\beta$ and augments the effects of distinct psychotropic medications. Mol. Psychiatry 2016, 21, 277-289. [CrossRef]

181. Coppell, A.L.; Pei, Q.; Zetterström, T.S.C. Bi-phasic change in BDNF gene expression following antidepressant drug treatment. Neuropharmacology 2003, 44, 903-910. [CrossRef]

182. Reddy, K.K.; Lefkove, B.; Chen, L.B.; Govindarajan, B.; Carracedo, A.; Velasco, G.; Carrillo, C.O.; Bhandarkar, S.S.; Owens, M.J.; Mechta-Grigoriou, F.; et al. The antidepressant sertraline downregulates Akt and has activity against melanoma cells. Pigment. Cell Melanoma Res. 2008, 21, 451-456. [CrossRef] [PubMed]

183. Lin, C.J.; Robert, F.; Sukarieh, R.; Michnick, S.; Pelletier, J. The Antidepressant Sertraline Inhibits Translation Initiation by Curtailing Mammalian Target of Rapamycin Signaling. Cancer Res. 2010, 70, 3199-3208. [CrossRef] [PubMed]

184. Jesinkey, S.R.; Korrapati, M.C.; Rasbach, K.A.; Beeson, C.C.; Schnellmann, R.G. Atomoxetine prevents dexamethasone-induced skeletal muscle atrophy in mice. J. Pharmacol. Exp. Ther. 2014, 351, 663-673. [CrossRef]

185. Shadfar, S.; Kim, Y.G.; Katila, N.; Neupane, S.; Ojha, U.; Bhurtel, S.; Srivastav, S.; Jeong, G.S.; Park, P.H.; Hong, J.T.; et al. Neuroprotective Effects of Antidepressants via Upregulation of Neurotrophic Factors in the MPTP Model of Parkinson's Disease. Mol. Neurobiol. 2018, 55, 554-566. [CrossRef] [PubMed]

186. Rahimi, B.M.; Motaghinejad, M.; Motevalian, M.; Gholami, M. Duloxetine by Modulating the Akt/GSK3 Signaling Pathways Has Neuroprotective Effects against Methamphetamine-Induced Neurodegeneration and Cognition Impairment in Rats. Iran J. Med. Sci. 2019, 44, 146-154.

187. Anttila, S.A.; Leinonen, E.V. A review of the pharmacological and clinical profile of mirtazapine. CNS Drug Rev. 2001, 7, 249-264. [CrossRef]

188. Engel, D.; Zomkowski, A.D.E.; Lieberknecht, V.; Rodrigues, A.L.; Gabilan, N.H. Chronic administration of duloxetine and mirtazapine downregulates proapoptotic proteins and upregulates neurotrophin gene expression in the hippocampus and cerebral cortex of mice. J. Psychiatr. Res. 2013, 47, 802-808. [CrossRef]

189. Couch, Y.; Anthony, D.C.; Dolgov, O.; Revischin, A.; Festoff, B.; Santos, A.I.; Steinbusch, H.W.; Strekalova, T. Microglial activation, increased TNF and SERT expression in the prefrontal cortex define stress-altered behaviour in mice susceptible to anhedonia. Brain Behav. Immun. 2013, 29, 136-146. [CrossRef]

190. Beaulieu, J.M.; Gainetdinov, R.R.; Caron, M.G. Akt/GSK3 Signaling in the Action of Psychotropic Drugs. Annu. Rev. Pharmacol. Toxicol. 2009, 49, 327-347. [CrossRef]

191. Park, S.W.; Lee, J.G.; Seo, M.K.; Lee, C.H.; Cho, H.Y.; Lee, B.J.; Seol, W.; Kim, Y.H. Differential effects of antidepressant drugs on mTOR signalling in rat hippocampal neurons. Int. J. Neuropsychopharmacol. 2014, 17, 1831-1846. [CrossRef]

192. Chen, M.J.; Russo-Neustadt, A.A. Running exercise- and antidepressant-induced increases in growth and survival-associated signaling molecules are IGF-dependent. Growth Factors 2007, 25, 118-131. [CrossRef] [PubMed]

193. Li, Y.; Zhang, Y.; Liu, Y.; Wang, H.; Yuan, L.; Luo, Z. Moclobemide up-regulates proliferation of hippocampal progenitor cells in chronically stressed mice. Acta Pharmacol. Sin. 2004, 25, 1408-1412. [PubMed]

194. Mines, M.A.; Jope, R.S. Brain region differences in regulation of Akt and GSK3 by chronic stimulant administration in mice. Cell. Signal. 2012, 24, 1398-1405. [CrossRef] [PubMed]

195. Hadj Ayed Tka, K.; Mahfoudh, B.A.; Zaouali, M.A.; Kammoun, R.; Bejaoui, M.; Ghoul, M.S.; Rosello, C.J.; Ben, A.H. Melatonin Modulates Endoplasmic Reticulum Stress and Akt/GSK3-Beta Signaling Pathway in a Rat Model of Renal Warm Ischemia Reperfusion. Anal. Cell. Pathol. 2015, 2015, 1-10. [CrossRef] [PubMed]

196. Dubovsky, S.L.; Warren, C. Agomelatine, a melatonin agonist with antidepressant properties. Expert Opin. Investig. Drugs 2009, 18, 1533-1540. [CrossRef] [PubMed]

197. Daniele, S.; Zappelli, E.; Martini, C. Trazodone regulates neurotrophic/growth factors, mitogen-activated protein kinases and lactate release in human primary astrocytes. J. Neuroinflammation 2015, 12, 225. [CrossRef]

198. Stambolic, V.; Ruel, L.; Woodgett, J.R. Lithium inhibits glycogen synthase kinase-3 activity and mimics wingless signalling in intact cells. Curr. Biol. 1996, 6, 1664-1668. [CrossRef]

199. Ryves, W.J.; Harwood, A.J. Lithium Inhibits Glycogen Synthase Kinase-3 by Competition for Magnesium. Biochem. Biophys. Res. Commun. 2001, 280, 720-725. [CrossRef] 
200. Chalecka-Franaszek, E.; Chuang, D.M. Lithium activates the serine/threonine kinase Akt-1 and suppresses glutamate-induced inhibition of Akt-1 activity in neurons. Proc. Natl. Acad. Sci. USA 1999, 96, 8745-8750. [CrossRef]

201. De Sarno, P.; Li, X.; Jope, R.S. Regulation of Akt and glycogen synthase kinase-3 beta phosphorylation by sodium valproate and lithium. Neuropharmacology 2002, 43, 1158-1164. [CrossRef]

202. Beaulieu, J.M.; Marion, S.; Rodriguiz, R.M.; Medvedev, I.O.; Sotnikova, T.D.; Ghisi, V.; Wetsel, W.C.; Lefkowitz, R.J.; Gainetdinov, R.R.; Caron, M.G. A $\beta$-arrestin 2 Signaling Complex Mediates Lithium Action on Behavior. Cell 2008, 132, 125-136. [CrossRef] [PubMed]

203. Tyler, M.W.; Yourish, H.B.; Ionescu, D.F.; Haggarty, S.J. Classics in Chemical Neuroscience: Ketamine. ACS Chem. Neurosci. 2017, 8, 1122-1134. [CrossRef] [PubMed]

204. Duman, R.S.; Li, N.; Liu, R.J.; Duric, V.; Aghajanian, G. Signaling pathways underlying the rapid antidepressant actions of ketamine. Neuropharmacology 2012, 62, 35-41. [CrossRef]

205. Homayoun, H.; Moghaddam, B. NMDA Receptor Hypofunction Produces Opposite Effects on Prefrontal Cortex Interneurons and Pyramidal Neurons. J. Neurosci. 2007, 27, 11496-11500. [CrossRef]

206. Jourdi, H.; Hsu, Y.T.; Zhou, M.; Qin, Q.; Bi, X.; Baudry, M. Positive AMPA Receptor Modulation Rapidly Stimulates BDNF Release and Increases Dendritic mRNA Translation. J. Neurosci. 2009, 29, 8688-8697. [CrossRef]

207. Réus, G.Z.; Vieira, F.G.; Abelaira, H.M.; Michels, M.; Tomaz, D.B.; dos Santos, M.A.B.; Carlessi, A.S.; Neotti, M.V.; Matias, B.I.; Luz, J.R.; et al. MAPK signaling correlates with the antidepressant effects of ketamine. J. Psychiatr. Res. 2014, 55, 15-21. [CrossRef]

208. Beurel, E.; Grieco, S.F.; Amadei, C.; Downey, K.; Jope, R.S. Ketamine-induced inhibition of glycogen synthase kinase-3 contributes to the augmentation of $\alpha$-amino-3-hydroxy-5-methylisoxazole-4-propionic acid (AMPA) receptor signaling. Bipolar Disord. 2016, 18, 473-480. [CrossRef]

209. Beurel, E.; Song, L.; Jope, R.S. Inhibition of glycogen synthase kinase-3 is necessary for the rapid antidepressant effect of ketamine in mice. Mol. Psychiatry 2011, 16, 1068-1070. [CrossRef]

210. Basar, K.; Eren-Kocak, E.; Ozdemir, H.; Ertugrul, A. Effects of Acute and Chronic Electroconvulsive Shocks on Glycogen Synthase Kinase $3 \beta$ Level and Phosphorylation in Mice. J. ECT 2013, 29, 261-266. [CrossRef]

(C) 2020 by the authors. Licensee MDPI, Basel, Switzerland. This article is an open access article distributed under the terms and conditions of the Creative Commons Attribution (CC BY) license (http://creativecommons.org/licenses/by/4.0/). 